Check for updates

Cite this: RSC Adv., 2020, 10, 29855

Received 9th July 2020

Accepted 31st July 2020

DOI: $10.1039 / \mathrm{dOra06002j}$

rsc.li/rsc-advances

\section{Revisiting the photochemical synthesis of [FeFe]- hydrogenase mimics: reaction optimization, mechanistic study and electrochemical behaviour $\dagger$}

\author{
Sergio Aguado, (D) ${ }^{a}$ Luis Casarrubios, (D) ${ }^{* a}$ Carmen Ramírez de Arellano (D) ${ }^{b}$ \\ and Miguel A. Sierra (iD *a
}

\begin{abstract}
The photoreaction of $\left[(\mu-\mathrm{S})_{2} \mathrm{Fe}_{2}(\mathrm{CO})_{6}\right]$ and alkenes or alkynes has been optimized to readily obtain functionalized [FeFe]-hydrogenase mimics. Irradiation under low CO pressure in THF produces the corresponding photo-adducts in good/acceptable (alkenes/alkynes) yields, with retention of the starting olefin stereochemistry. DFT-calculations provide plausible reaction pathways in both, singlet and triplet states. The DFT-calculation based in the singlet state is energetically more favorable. The electrochemical behavior of the synthesized compounds is also presented, including studies in acidic media. The electrochemical properties of the products vary in the presence of a double bond (cycloaddition of $\left[(\mu-\mathrm{S})_{2} \mathrm{Fe}_{2}(\mathrm{CO})_{6}\right]$ to alkynes), respect to a single bond (cycloaddition to alkenes).
\end{abstract}

\section{Introduction}

One of the challenges of chemistry in the 21st century is to develop viable methods to produce hydrogen. ${ }^{1}$ Hydrogenases are metalloenzymes able to generate molecular hydrogen by reducing protons in anaerobic media. ${ }^{2}$ The use of hydrogenase bio-inspired analogues is a promising option for the production of hydrogen. Current research in this field is mainly focused on two different approaches. The first one uses whole organisms, inorganic hybrids or supported enzymatic systems. ${ }^{3}$ The second approach uses mimics of hydrogenases, namely synthetic small molecules that when coupled to other reagents and catalysts are able to produce hydrogen. ${ }^{4}$

Fragment $\mathbf{I}$ is the basic motif of the hydrogen production moiety of a [FeFe]-hydrogenase (Fig. 1). Much synthetic research in this field targeted the preparation of mimics with a simplified structural motif II similar to $\mathbf{I}^{\mathbf{4}}{ }^{\boldsymbol{b}}$ A second group of $[\mathrm{FeFe}]-\mathrm{H}_{2}$ ase synthetic models has the $\left[(\mu-\mathrm{SR})_{2} \mathrm{Fe}_{2}(\mathrm{CO})_{6}\right]$ motif as the essential core (III in Fig. 1). ${ }^{4 a}$ This second group of mimics has been less studied in the photocatalytic production of hydrogen. ${ }^{4 c}$

\footnotetext{
${ }^{a}$ Departamento de Química Orgánica, Facultad de Ciencias Químicas, Center for Innovation in Advanced Chemistry (ORFEO-CINQA), Universidad Complutense, 28040-Madrid, Spain.E-mail: sierraor@ucm.es; lcasarru@ucm.es

${ }^{b}$ Departamento de Química Orgánica, Center for Innovation in Advanced Chemistry (ORFEO-CINQA), Universidad de Valencia, 46100-Valencia, Spain

$\dagger$ Electronic supplementary information (ESI) available: The graphics for the electrochemical measurements of complexes $\mathbf{4}$, the cartesian coordinates of species $4 \mathbf{e}, \mathbf{4} \mathrm{e}^{\cdot-}, \mathbf{4} \mathbf{g}$ and $4 \mathbf{g}^{\cdot-}$ as well as a copy of the IR and NMR spectra for all the new compounds prepared through this work. CCDC 1960548 contains the supplementary crystallographic data for compound 4d. For ESI and crystallographic data in CIF or other electronic format see DOI: 10.1039/d0ra06002j
}

The preparation of type III mimics is achieved by thermal reaction of either $\mathrm{Fe}_{2}(\mathrm{CO})_{9}$ or $\mathrm{Fe}_{3}(\mathrm{CO})_{12}$ and sulphides or disulphides to yield compounds having structure 1 (Scheme $1)^{4 b}$ This approach is versatile and provides access to sophisticated structures. However, again the reaction conditions are not tolerated by several classes of substrates. Additionally, the precursors of the sulphides or disulphides are not always easy to access. $^{5}$

An alternative and potentially useful approach to introduce the $\left[(\mu-S)_{2} \mathrm{Fe}_{2}(\mathrm{CO})_{6}\right] 2$ moiety into substrates not compatible

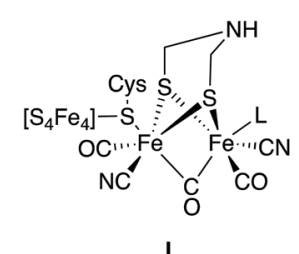

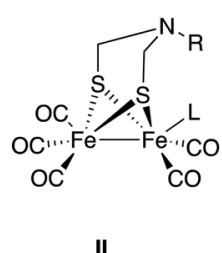

II

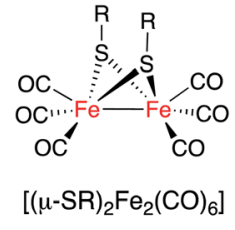

III
Fig. 1 Schematic representation of $[\mathrm{FeFe}]-\mathrm{H}_{2}$ ase active site (I) and their synthetic mimics (II and III).

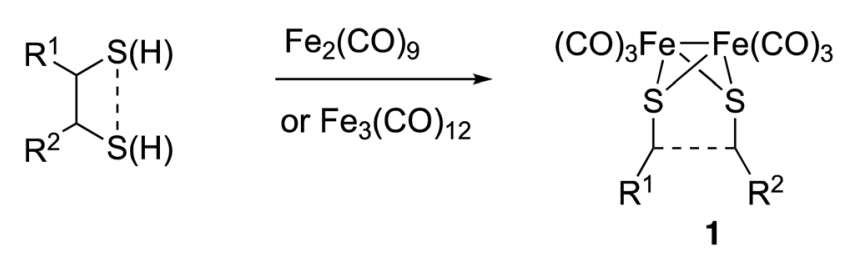

Scheme 1 Synthesis of [FeFe]-H $\mathrm{H}_{2}$ ase synthetic models. 
with the conditions used by standard approaches would be the photocycloaddition of $\left[(\mu-\mathrm{S})_{2} \mathrm{Fe}_{2}(\mathrm{CO})_{6}\right]$ and alkenes or alkynes. The photochemical reaction of 2 and simple unfunctionalized substrates has been previously reported. However, yields of photoreactions are usually very poor. Thus, irradiation of $[(\mu-$ $\left.\mathrm{S}_{2} \mathrm{Fe}_{2}(\mathrm{CO})_{6}\right] 2$ and simple olefins ${ }^{6}$ including 1 - and 2-pentene $3 \mathbf{a}$ and $\mathbf{3 b}$ yielded the corresponding photoadducts $\mathbf{4 a}$ and $\mathbf{4 b}$ in $6.9 \%$ and $8.9 \%$ yield, respectively (Scheme 2 ).

Similar low yields were obtained with both, acyclic ${ }^{6}$ and cyclic $^{7}$ dienes. The only exceptions are ethylene ${ }^{8}$ and $p$-benzoquinone, ${ }^{9}$ that produce the corresponding photoadducts in $65 \%$ and $53 \%$ yields, respectively. Finally, several $\mathrm{C}_{60}\left[\mathrm{~S}_{2} \mathrm{Fe}_{2}(\mathrm{CO})_{6}\right]_{n}(n$ $=1-6)$ and $\mathrm{C}_{70}\left[\mathrm{~S}_{2} \mathrm{Fe}_{2}(\mathrm{CO})_{6}\right]_{n}(n=1-4)$ mixtures were obtained from $\left[(\mu-\mathrm{S})_{2} \mathrm{Fe}_{2}(\mathrm{CO})_{6}\right]$ and $\mathrm{C} 60$ and $\mathrm{C} 70$ fullerenes. The $\mathrm{C}_{60}\left[\mathrm{~S}_{2} \mathrm{Fe}_{2}(\mathrm{CO})_{6}\right]$ adduct was separated from the mixture with a $52 \%$ yield based on recovered $\mathrm{C} 60$, while $\mathrm{C}_{70}\left[\mathrm{~S}_{2} \mathrm{Fe}_{2}(\mathrm{CO})_{6}\right]$ adduct was obtained with a $63 \%$ based on recovered $\mathrm{C} 70 .{ }^{10}$ The mechanism of these photoreactions remains unexplored. The mechanisms and synthetic applications for organometallic compounds photochemistry are intrinsically different from their all-carbon counterparts, being a subject of general interest. $^{11}$

Despite the reported low yields for the photocycloaddition of $\left[(\mu-S)_{2} \mathrm{Fe}_{2}(\mathrm{CO})_{6}\right]$ and alkenes/alkynes, this reaction may be a good alternative to include this [FeFe] moiety into substrates incompatible with the reaction condition used by other synthetic approaches to these classes of compounds. We report herein a useful optimized approach to incorporate the $[(\mu-$ $S)_{2} \mathrm{Fe}_{2}(\mathrm{CO})_{6}$ ] into smooth reaction conditions to different classes of substrates, as well as a proposal for the reaction mechanism using DFT calculations.

\section{Results and discussion}

Complex $\left[(\mu-S)_{2} \mathrm{Fe}_{2}(\mathrm{CO})_{6}\right] 2$ and 1-hexene were used to tune up the reaction conditions. Light source and solvent were first investigated. Thus, irradiation of equimolar amounts of $[(\mu-$ $\left.\mathrm{S}_{2} \mathrm{Fe}_{2}(\mathrm{CO})_{6}\right]$ and 1-hexene in anhydrous THF using $4 \times 60 \mathrm{~W}$ blue light LEDs did not produce any reaction product. The reagents were recovered unaltered after 72 hours of irradiation. The use of medium pressure Hg-lamps (Pyrex filter and Pyrex well) produced the desired photoadduct $4 \mathrm{c}$ in $31 \%(400 \mathrm{~W})$ and $47 \%(125 \mathrm{~W})$ isolated yields. A $6.9 \%$ yield for the reaction of 1pentene and $\left[(\mu-S)_{2} \mathrm{Fe}_{2}(\mathrm{CO})_{6}\right]$, using a high-pressure Hg-lamp

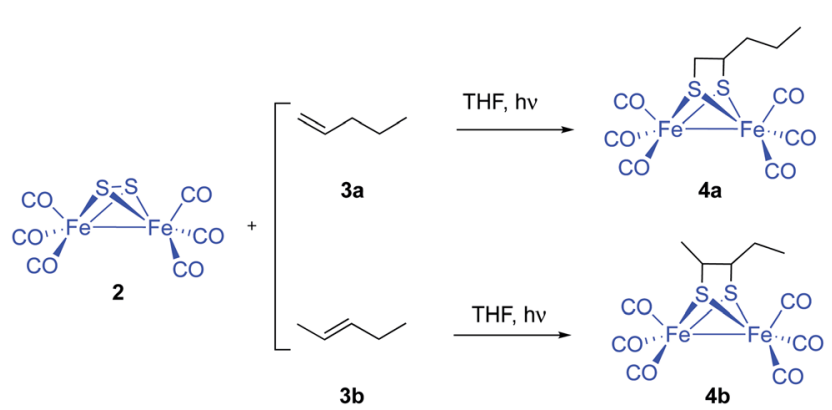

Scheme 2 Photocycloaddition of 2 with 1- and 2-pentene $3 a$ and $3 b$.
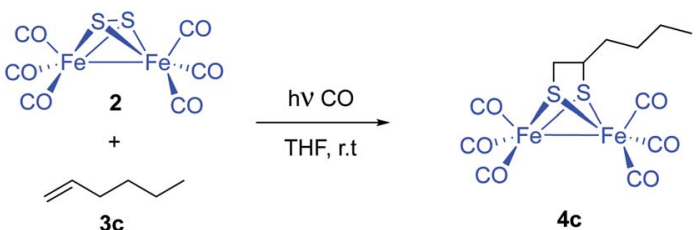

$4 \times 60 \mathrm{~W}$ blue LEDs: no reaction medium pressure 400W Hg Lamp: $31 \%$ medium pressure $125 \mathrm{~W}$ Hg Lamp: $47 \%$ medium pressure 125W Hg Lamp (CO, $1 \mathrm{~atm})$ : $64 \%$
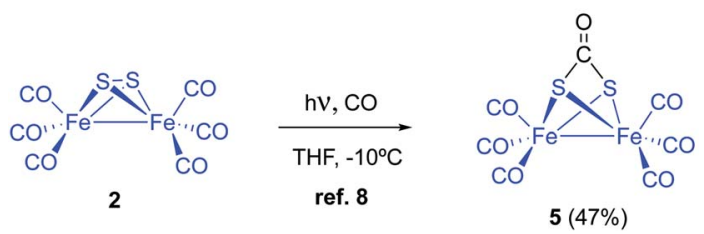

Scheme 3 Photochemical reaction between $\left[(\mu-\mathrm{S})_{2} \mathrm{Fe}_{2}(\mathrm{CO})_{6}\right] 2$ and olefins or alkynes 3. Initial optimizations.

and quartz glassware, was previously reported. Thus, filtering the UV component of the irradiation source clearly increases the reaction yield. This yield improvement is probably due to a smaller decomposition of the diiron complexes by the COligands photo-removing effect (see below). Other solvents like MeCN (14\%), benzene (18\%), and $\mathrm{Et}_{2} \mathrm{O}(11 \%)$ produced lower isolated yields of the adduct $4 \mathbf{c}$ (Scheme 3 ).

Dependence of yields with the choice of solvent pointed to a competitive light-induced CO dissociation leading to, either decomposition or tetrameric species. ${ }^{\mathbf{1 2}}$ Thus, THF would fill iron coordination vacants avoiding or retarding competitive undesired reactions. This hypothesis would imply a yield increment under CO-atmosphere. However, it has been reported that complex $\left[(\mu-\mathrm{S})_{2} \mathrm{Fe}_{2}(\mathrm{CO})_{6}\right]$ reacts with $\mathrm{CO}$ to form the $\mathrm{CO}$ adduct 5 with a $47 \%$ yield (Scheme 3$).{ }^{8}$ Nevertheless, the reaction of $\left[(\mu-\mathrm{S})_{2} \mathrm{Fe}_{2}(\mathrm{CO})_{6}\right] 2$ and 1-hexene was repeated under 1 atm (14 psi) of CO and, compound $4 \mathrm{c}$ was obtained with a $64 \%$ isolated yield. The reaction crude material was cleaner and decomposition of the starting diiron complex 2 was not observed. Therefore, it is clear that CO atmosphere hampers the photo-extrusion of $\mathrm{CO}$ and thence the decomposition of the $[(\mu-$ $\left.\mathrm{S})_{2} \mathrm{Fe}_{2}(\mathrm{CO})_{6}\right]$, increasing the reaction yields. However, the use of higher pressures of CO (40 psi) resulted in lower yields of the desired product. Competitive CO insertion to produce 5 might be the cause of these lower yields. ${ }^{8}$

Fine tuning of the reaction conditions of this photocycloaddition allows a yield increment from the described 6-9\% up to $65 \%$ in the case of simple aliphatic olefins. Functionalized alkenes like $N$-phenylmaleimide $3 \mathbf{d}$ and methyl acrylate $3 \mathbf{e}$ were reacted with $\left[(\mu-S)_{2} \mathrm{Fe}_{2}(\mathrm{CO})_{6}\right] 2$ to form the corresponding photoadducts $4 \mathbf{d}$ and $4 \mathrm{e}$ with $70 \%$ and $86 \%$ isolated yields, respectively. These yields were achieved with THF as the choice solvent under $1 \mathrm{~atm}$ of $\mathrm{CO}$ and a $125 \mathrm{~W}$ medium pressure $\mathrm{Hg}$ lamp (Pyrex filter and Pyrex well) (Scheme 4).

Series of both, terminal and disubstituted alkynes were next tested as starting substrates. $p$-Tolyl acetylene $3 \mathbf{f}$ formed the corresponding adduct $\mathbf{4 f}$ in $45 \%$ yield, while methyl propyolate 

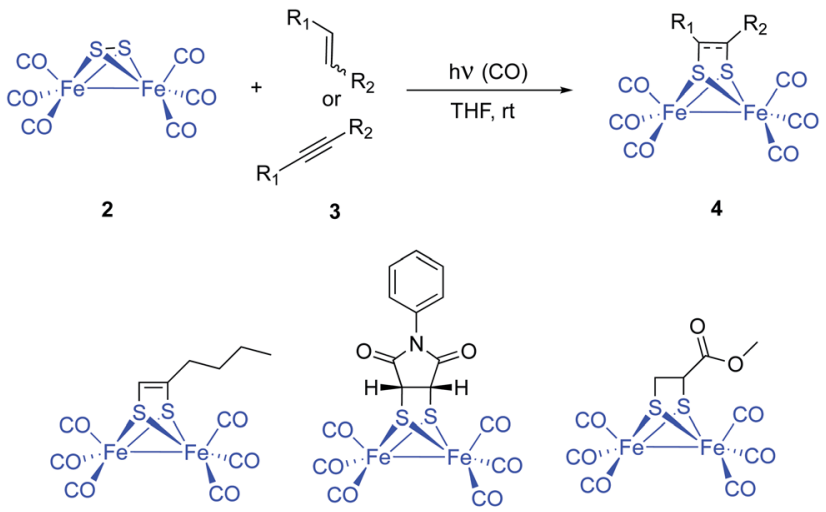

4d $(70 \%)$

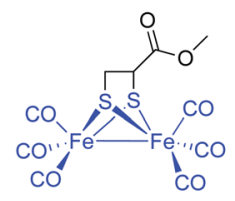

$4 c(64 \%)$
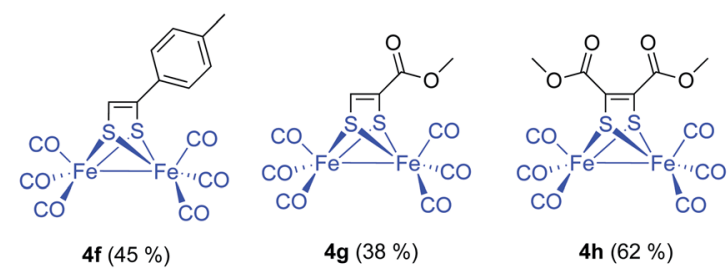

Scheme 4 Photochemical reaction of $\left[(\mu-\mathrm{S})_{2} \mathrm{Fe}_{2}(\mathrm{CO})_{6}\right]$ with olefins and alkynes. Substrate scope.

$\mathbf{3 g}$ and dimethyl acetylendicarboxylate $\mathbf{3 h}$ yielded the corresponding adducts $4 \mathrm{~g}$ (38\%) and $\mathbf{4 h}(62 \%)$. Although functionalized alkynes formed the corresponding cycloadducts in lower yields than those obtained for alkenes, they could be used as substrates for the cycloaddition process. Therefore, the method is general and tolerates a variety of functional groups (vide infra). ${ }^{13}$

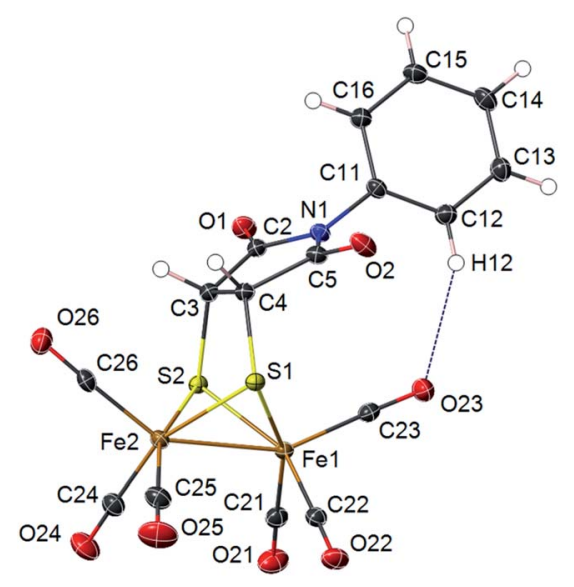

Fig. 2 X-ray thermal ellipsoid plot for compound $4 d$ (50\% probability level) showing a $\mathrm{C}-\mathrm{H} \cdots \mathrm{OC}$ intramolecular interaction. Selected bond lengths $(\AA \AA)$ and angles $\left({ }^{\circ}\right)$ : $\mathrm{Fe}(1)-\mathrm{Fe}(2) 2.4966(3), \mathrm{Fe}(1)-C(21) 1.7983(15)$, $\mathrm{Fe}(1)-C(22) 1.7990(15), \mathrm{Fe}(1)-C(23)$ 1.8102(15), $\mathrm{Fe}(1)-S(1) 2.2428(4)$, $\mathrm{Fe}(1)-\mathrm{S}(2)$ 2.2473(4), $\mathrm{Fe}(2)-\mathrm{C}(24)$ 1.7995(16), $\mathrm{Fe}(2)-\mathrm{C}(25)$ 1.8004(16), $\mathrm{Fe}(2)-\mathrm{C}(26) 1.8077(15), \mathrm{Fe}(2)-\mathrm{S}(1) 2.2521(4), \mathrm{Fe}(2)-\mathrm{S}(2) 2.2513(4), \mathrm{S}(1)-$ $C(4) 1.8289(4), S(2)-C(3) 1.8434(4), C(3)-C(4) 1.5203(18), S(1)-F e(1)-$ $\mathrm{S}(2)$ 81.488(14), S(1)-Fe(2)-S(2) 81.197(13), Fe(1)-S(1)-Fe(2) 67.478(12), $\mathrm{Fe}(1)-\mathrm{S}(2)-\mathrm{Fe}(2) 67.416(12), \mathrm{C}(31)-\mathrm{N}(1)-\mathrm{C}(2) 119.64(10), \mathrm{C}(31), \mathrm{C}(12) \ldots$ $\mathrm{O}(23) 3.310(2) \AA ; \mathrm{H}(12) \cdots \mathrm{O}(23) 2.45 \AA$; $\mathrm{C}(12)-\mathrm{H}(12) \cdots \mathrm{O}(23) 150.7^{\circ}$.
Photoadducts derived from the reaction of 2 with olefins could be formed either as cis- or trans-isomers in the newly formed metallacycle. The symmetry of our molecules avoids the assignation of the cis-trans stereochemistry by conventional NMR techniques. Crystals of compound 4d suitable for X-ray diffraction were grown from a DCM/hexane solution. The Xray structure determination of $\mathbf{4 d}$ unambiguously confirms the cis arrangement of the fused bicyclic system (Fig. 2). Molecular structure of $\mathbf{4 d}$ shows a $\left[(\mu-\mathrm{SR})_{2} \mathrm{Fe}_{2}(\mathrm{CO})_{6}\right]$ complex with a butterfly structure for the $[2 \mathrm{Fe}-2 \mathrm{~S}]$ cluster. Both iron atoms adopt a distorted square-pyramidal geometry. The $\mathrm{Fe}-\mathrm{Fe}$ bond length (2.4966(3) $⿱$ ) lies in the range found for similar ethylenedithiolate-hexacarbonyl-di-iron structures $^{\mathbf{1 4}}$ (2.454$2.546 \AA$ ). Fe-Fe bond length in compound $4 \mathrm{~d}$ is shorter than in metalloenzymes Hydrogenase DdI ( $c a$. 2.55 $⿱$ A) or CpI ( $c a .2 .62$ A). ${ }^{15}$ The dithiolate bridging ligand and both iron atoms form two fused five-membered metallocycles with the nitrogen substituent N-Ph group bending towards the Fe(1) atom. This conformation implies short intramolecular distances between the nitrogen atom $\mathrm{N}(1)$ and the closest carbonyl group $\mathrm{C}(23)-$ $\mathrm{O}(23)[\mathrm{N}(1) \cdots \mathrm{C}(23) \quad 3.221(2) \AA \circ$; $\mathrm{N}(1) \cdots \mathrm{O}(23)$ 3.609(7) $\mathrm{A}]$. An intramolecular $\mathrm{C}-\mathrm{H} \cdots \mathrm{OC}-\mathrm{Fe}$ interaction is observed $[\mathrm{C}(12) \cdots$ $\mathrm{O}(23) 3.310(2) \AA$; $\mathrm{H}(12) \cdots \mathrm{O}(23) 2.45 \AA$; $\mathrm{C}(12)-\mathrm{H}(12) \cdots \mathrm{O}(23)$ $\left.150.7^{\circ}\right]$. This interaction lies within the expected parameters for an intramolecular $\mathrm{C}-\mathrm{H} \cdots \mathrm{OC}-\mathrm{Fe}$ hydrogen bond with the oxygen of a terminal carbonyl group acting as a hydrogen bond acceptor (i.e. mean values $\mathrm{C} \cdots \mathrm{O} 3.50 \AA$ А; $\mathrm{H} \cdots \mathrm{O} 2.64 \AA$; $\mathrm{C}-\mathrm{H} \cdots \mathrm{O}$ $\left.138.0^{\circ}\right) .{ }^{16}$ Interactions between $N$-arene group and the closest carbonyl group has been previously described to produce an enlargement on the $\mathrm{C}-\mathrm{Fe}-\mathrm{Fe}$ angle for the implicated carbonyl group in azadithiolates diirion structures. ${ }^{5,17}$ Thus, in compound $4 \mathrm{~d}$ the $\mathrm{C}(23)-\mathrm{Fe}(1)-\mathrm{Fe}(2)$ angle is $5.25(5)^{\circ}$ larger than the $\mathrm{C}(26)-\mathrm{Fe}(2)-\mathrm{Fe}(1)$ angle.

Substrates having electroactive moieties were next tested. Methyl trans-2-ferrocenylacrylate $3 \mathbf{i}$ reacts with 2 and the

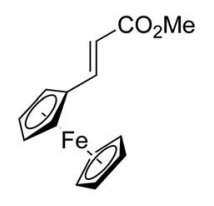

$3 \mathbf{i}$<smiles>C#Cc1ncnc2c1ncn2C1OC(COC(C)=O)[C@H](OC(C)=O)[C@H]1OC(C)=O</smiles>

3j

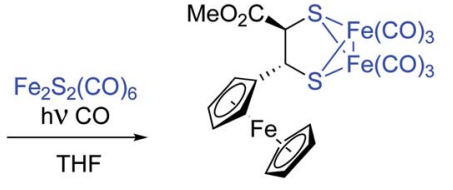

$4 \mathbf{i}(43 \%)$

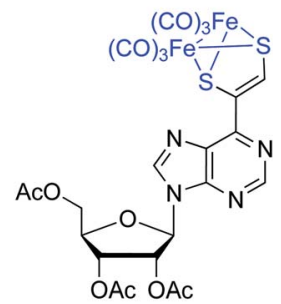

4j (24\%)
Scheme 5 Photochemical reaction between $\left[(\mu-\mathrm{S})_{2} \mathrm{Fe}_{2}(\mathrm{CO})_{6}\right]$ and olefins or alkynes. Compatibility of the process with functionalized substrates. Compound $4 \mathbf{i}$ was a racemic material, one single enantiomer is represented for simplicity. 
corresponding photo-adduct $\mathbf{4 i}$ is isolated in $43 \%$ yield. The trans stereochemistry of the starting ferrocene derived olefin $\mathbf{3 i}$ is again maintained in the final adduct $(\delta=4.13$ and $3.16 \mathrm{ppm}$, $\mathrm{d}, J=6.3 \mathrm{~Hz}$ for both $\underline{\mathrm{CH}}-\mathrm{S}$ groups). To confirm that the stereochemistry of the starting material is retained in the photocycloaddition, NOE experiments were performed for complex $4 \mathbf{i}$ on a $500 \mathrm{MHz}$ NMR spectrometer. Irradiation of the signal at $3.16 \mathrm{ppm}$, corresponding to the $\mathrm{CH}-\mathrm{CO}$ proton, showed a main NOE effect with the proton at $3.98 \mathrm{ppm}$ (substituted Cp ring). This observed NOE effect points to a trans relative disposition of the $\mathrm{CO}_{2} \mathrm{Me}$ and the $\mathrm{Fc}$ moieties which is in good agreement with the concerted proposed calculated mechanism (see below).

Nucleotide $\mathbf{3 j}$ was next tested. In this case the product incorporating the $\left[(\mu-\mathrm{S})_{2} \mathrm{Fe}_{2}(\mathrm{CO})_{6}\right]$ moiety was obtained with a $24 \%$ isolated yield. Despite the high functionalization of $3 \mathbf{j}$, no by-products were obtained, and unaltered starting materials could be recovered (Scheme 5).

The possibility of achieving a double photocycloaddition to obtain tetrametallic systems is also addressed. $N, N^{\prime}-(1,4-$ phenylene)dimaleimide $3 \mathbf{k}$ reacts with $\left[(\mu-\mathrm{S})_{2} \mathrm{Fe}_{2}(\mathrm{CO})_{6}\right]$, with no further reaction progress observed (tlc) after 15 hours of irradiation. From the crude reaction mixture, tetrametallic complex $4 \mathbf{k}$ was obtained with a $26 \%$ isolated yield. An analogous reaction was carried out with ferrocene complex 31. A mixture of pentametallic complex $\mathbf{4 m}$ (single diastereomer, 52\%) and trimetallic complex $\mathbf{4 1}$ (35\%) was obtained. It is worthy to note that the four stereogenic centers of complex $\mathbf{4 m}$ are formed in a totally stereoselective way maintaining the configuration of the starting olefins (Scheme 6). A high degree of diastereoselectivity has also been achieved in this reaction. An analogous result was obtained from the bis-allyl derivative of hydroquinone 30 which lead to a mixture of dimetallic 40 and tetrametallic complex $4 \mathbf{p}$ in $55 \%$ and $20 \%$ isolated yields, respectively. Although the analysis of the crude mixtures of $\mathbf{4 p}$ showed a single product, there are no reasons to believe that a complete stereoselectivity was achieved in this case. Probably, $\mathbf{4 p}$ is a mixture of diastereomers but the chiral centres are wellseparated and the differences in their NMR data may be null. Finally, the bis-propargyl derivative of hydroquinone $3 \mathbf{n}$ was not able to form the tetrametallic derivative, while bimetallic derivative 4n was obtained with just a 17\% yield (Scheme 6). This is in good agreement with the observed lower reactivity of alkynes.

\section{Mechanistic studies}

According to a previous theoretical study, ${ }^{18}$ irradiation of the starting diiron complex 2 with UV-light would generate two butterfly isomers or a rhombus isomer by breaking one or both of the Fe-Fe and S-S bonds (see Fig. 4 in ref. 18). This study concludes that photochemical reactions of complex 2 should proceed through Fe-Fe butterfly biradical $\mathrm{Fe}_{2}(\mathrm{CO})_{6} \mathrm{~S}_{2}$ intermediates (Fig. 3).

However, optimization of the Fe-Fe butterfly using unrestricted uBP86 functional together with the command guess(mix, always) or restricted BP86 yielded the same energy minimum. Careful examination of the spin densities and bond distances in the output files did not match a biradical species in any case. Optimization of the reaction pathway was calculated for the cycloaddition between starting complex 2 and both,
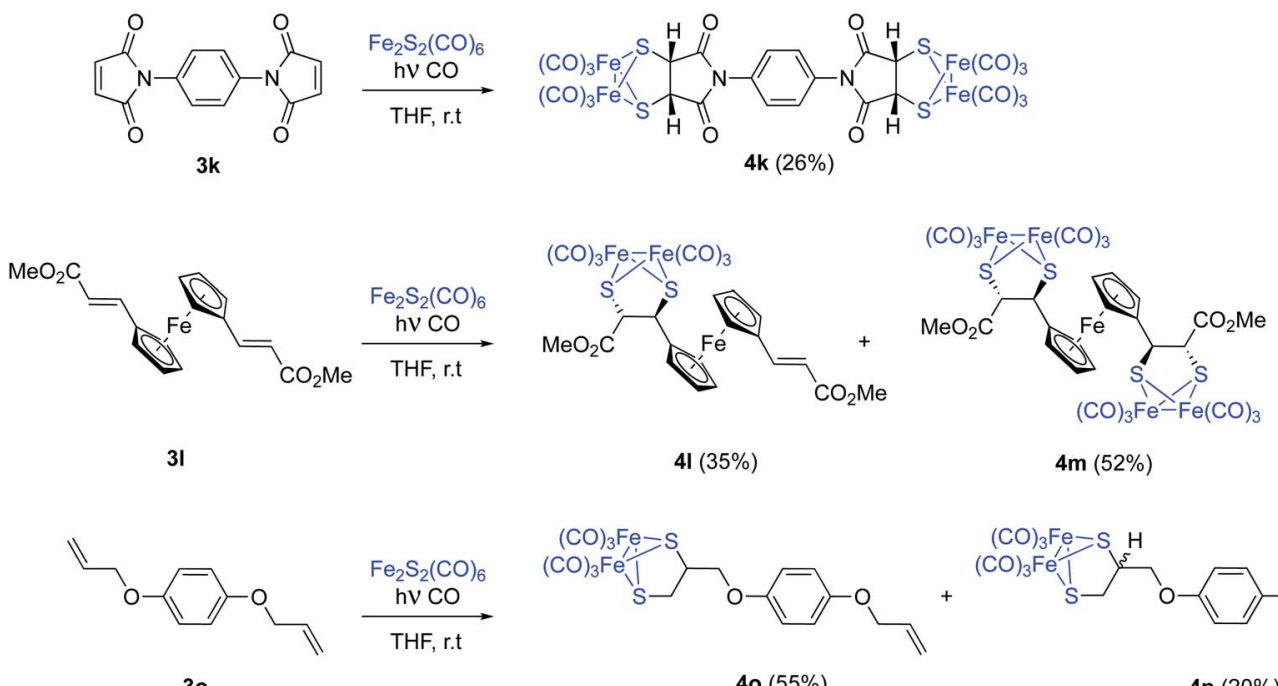

$4 \mathrm{~m}(52 \%)$

30

$40(55 \%)$

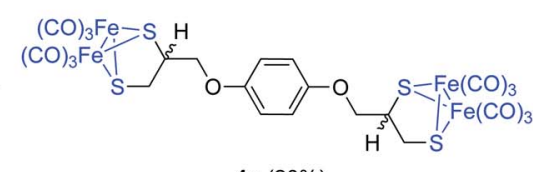

$4 \mathrm{p}(20 \%)$

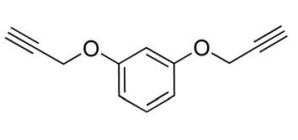

$3 n$
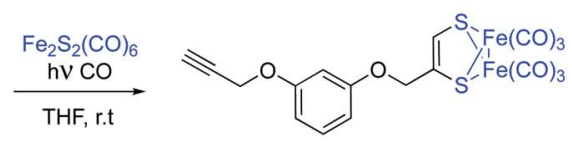

4 n $(17 \%)$

Scheme 6 Photochemical reaction between $\left[(\mu-S)_{2} \mathrm{Fe}_{2}(\mathrm{CO})_{6}\right]$ and olefins or alkynes. Synthesis of polymetallic systems. Compounds $4 \mathrm{l}, 4 \mathrm{~m}$ were racemic mixtures. Only one enantiomer is depicted for clarity. 


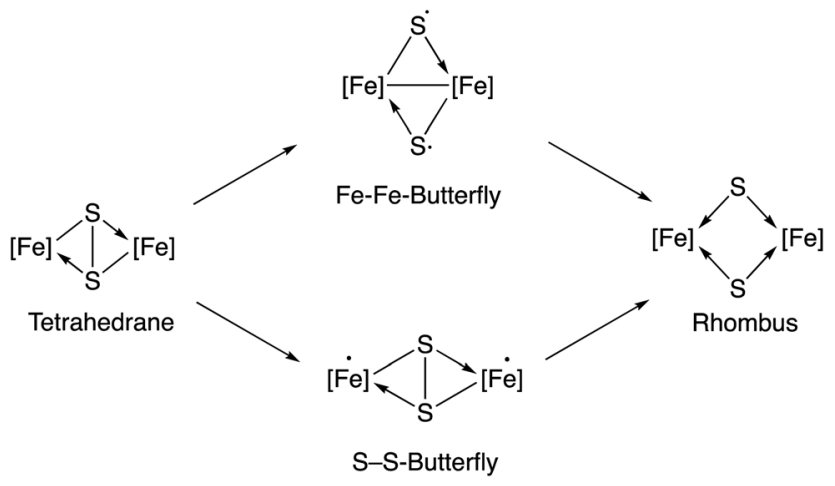

Fig. 3 Species implied in the photolysis of complex 2 according to Bruce King et al. ${ }^{18}$

methyl propiolate $\mathbf{3 g}$ (Scheme 7) and methyl acrylate $\mathbf{3 e}$ (Scheme 8).

We first tested the possibility of reacting methyl propiolate with the FeFe-butterfly intermediate in the singlet state. In order to contemplate the possibility of biradicals implied in the process, broken spin symmetry [UBP86 + guess(mix, always)] was compared to restricted RBP86. Both calculations for the first TS of the pathway converged to the same minimum which should, in principle, discard a triplet diradical reaction pathway. Restricted singlet-state calculations for a concerted cycloaddition reaction are shown in Scheme 7. An alternative pathway involving triplet excited states was also contemplated. This process should involve a stepwise cycloaddition having a $\Delta \Delta G^{\ddagger}=30.1 \mathrm{kcal} \mathrm{mol}^{-1}$ in the rate-determining step, which makes the process less probable than the concerted pathway $\left(\Delta \Delta G^{\ddagger}=9.9 \mathrm{kcal} \mathrm{mol}^{-1}\right)$. Moreover, the calculated final product 6 for this alternative mechanism has a structure different to the experimentally isolated complex $\mathbf{4 g}$. These species, lacking one $\mathrm{Fe}-\mathrm{S}$ bond were not observed in any of the experiments carried out in this work. ${ }^{19}$

The reaction of complex 2 and methyl acrylate $3 \mathbf{e}$ was also calculated in the singlet and triplet spin states. Results for the singlet state are similar to those obtained for the methyl propiolate. A concerted reaction pathway with a low activation barrier $\left(\Delta \Delta G^{*}=8.7 \mathrm{kcal} \mathrm{mol}^{-1}\right)$ drives the reaction to the formation of the experimentally isolated product 4e. Unrestricted UBP86 singlet state was also tested and again it converged to the same energy minimum obtained with restricted BP86 one. While the triplet initial state of the reagents was found to be only $5.7 \mathrm{kcal} \mathrm{mol}^{-1}$ over the singlet, the two steps process was found to have an overall $\Delta \Delta G^{\ddagger}$ of $35.2 \mathrm{kcal}$ $\mathrm{mol}^{-1}$ which makes this process unfavorable when compared to the singlet concerted cycloaddition mechanism (Scheme 8). Therefore, we can safely conclude that the photoreaction of $[(\mu-$ $\left.\mathrm{S})_{2} \mathrm{Fe}_{2}(\mathrm{CO})_{6}\right]$ with alkenes and alkynes is a concerted process, which additionally accounts for the observed retention of the stereochemistry of the starting olefins into the obtained final products. ${ }^{20}$

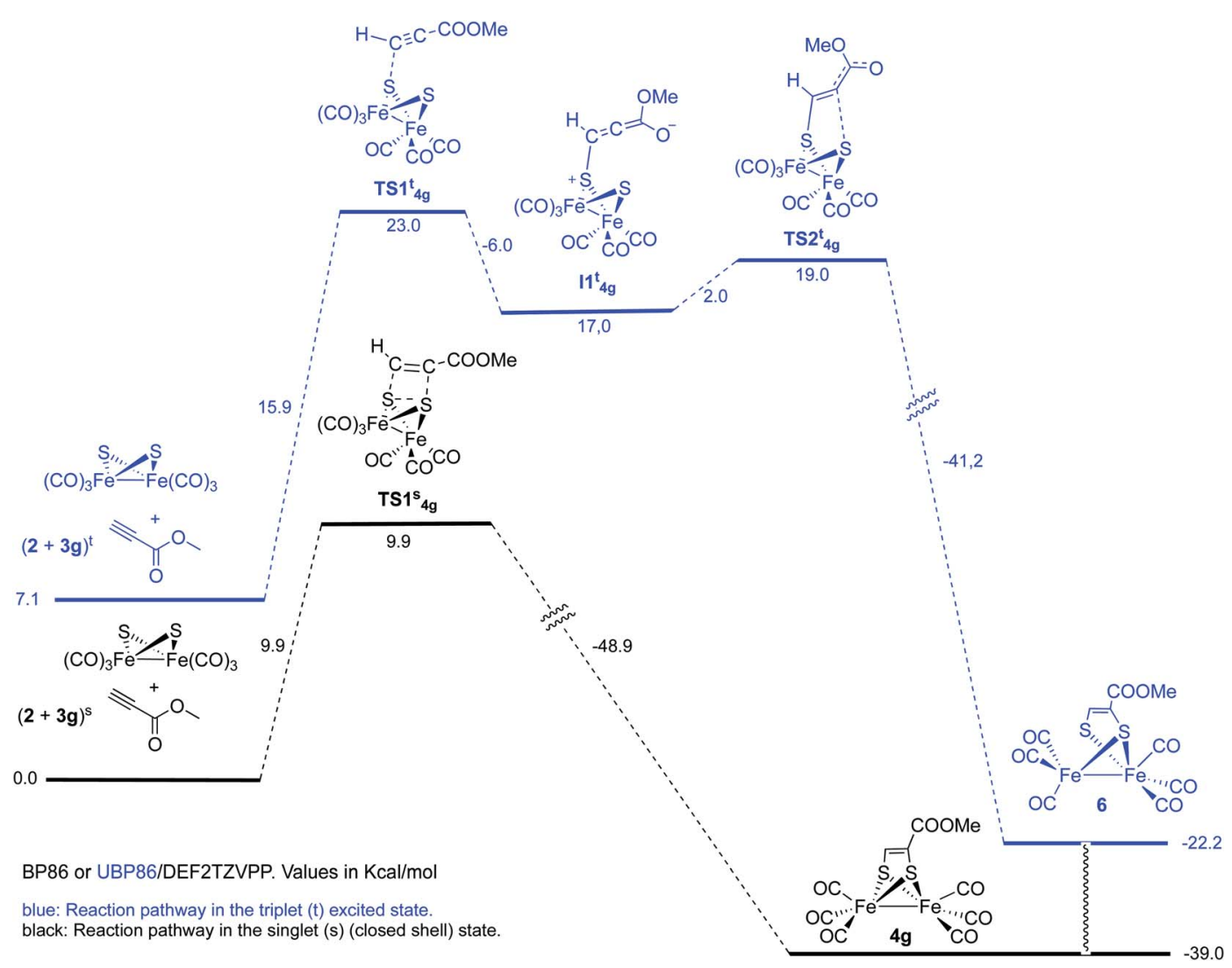

Scheme 7 Reaction of complex 2 with methyl propiolate $3 g$ 


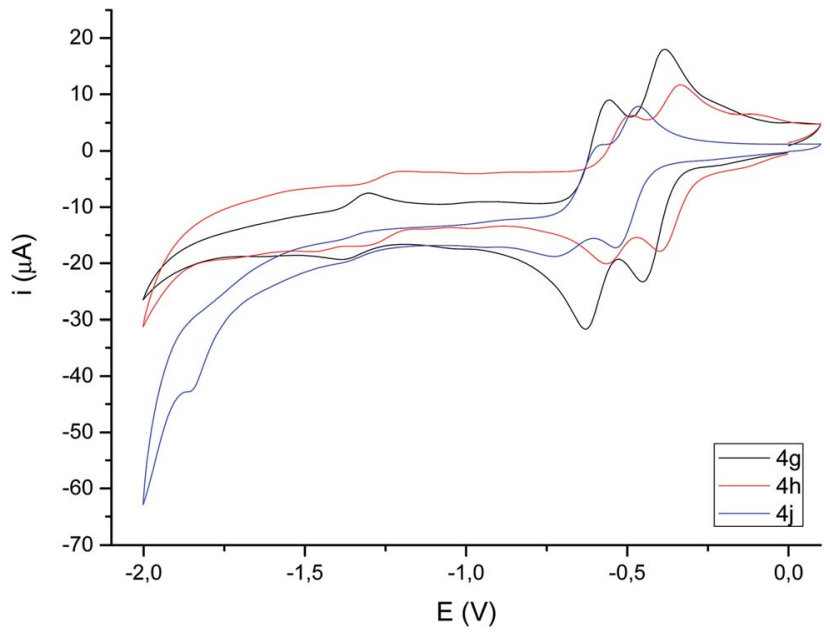

Fig. 4 Cyclic voltammograms (focused on reduction) of selected compounds $4 \mathrm{c}, \mathrm{d}\left(10^{-3} \mathrm{M}\right.$ in $\left.\mathrm{CH}_{3} \mathrm{CN}\right), 10^{-1} \mathrm{M}\left[N\left({ }^{n} \mathrm{Bu}\right)_{4}\right] \mathrm{PF}_{6}$, counterelectrode: Pt; working electrode: glassy carbon; reference electrode: $\mathrm{Ag} / \mathrm{AgCl}$; scan rate: $100 \mathrm{mV} \mathrm{s}{ }^{-1}$; values given in V. For full voltammograms see the ESI.†

\section{Electrochemistry}

Cyclic voltammograms of compounds 4 were recorded in $\mathrm{CH}_{3} \mathrm{CN}$ solution vs. $\mathrm{Ag} / \mathrm{AgCl}(3 \mathrm{M})$. The reduction of the compounds clearly depends on the presence of a double bond in the bimetallic cycle. Thus, while alkene-derived products (for example 4c-e) show a quasi-reversible reduction wave at about $-1.44 \mathrm{~V}$ to $-1.61 \mathrm{~V}$, assigned to a one-electron $\left[\mathrm{Fe}^{\mathrm{I}} \mathrm{Fe}^{\mathrm{I}}\right] /\left[\mathrm{Fe}^{0} \mathrm{Fe}^{\mathrm{I}}\right]$ process, ${ }^{21}$ the analogous alkyne-derived compounds (for example $4 \mathbf{f}-\mathbf{h}$ ) show two quasi-reversible reduction waves about $-0.92 \mathrm{~V}$ to $-1.03 \mathrm{~V}$ and $-1.08 \mathrm{~V}$ to $-1.20 \mathrm{~V}$ (Fig. 4 and Table 1 ). Alkyne-derived compounds present a double bond within the metallacycle that is not present for alkene-derived compounds.

Compounds derived from alkenes behave like the analogous derivatives having $\left[(\mu-\mathrm{SR})_{2} \mathrm{Fe}_{2}(\mathrm{CO})_{6}\right]$ structures. $^{21}$
However, compounds derived from alkynes show a strongly displaced anodic wave (even lower than those derivatives of type II in Fig. 1), together with the new reversible wave (see Fig. 5 for comparison). A similar behaviour has been reported for complex 4h. ${ }^{22}$ DFT calculations (BP86/Def2tzvpp/SCRF, CPCM-MeCN) were performed for further understanding this anodic displacement and the electrochemistry of these complexes. The LUMO in complex $4 \mathbf{e}$ is clearly centered in the [FeFe] moiety, while the LUMO of complex $\mathbf{4 g}$ having a double bond has a strong component in the organic moiety of the metallacycle (Fig. 6). Therefore, the strong anodic displacement caused by the presence of one double bond in the metallacycle may be explained by the reception of the electron by the organic moiety. Contrary to the complexes having one double bond those complexes having a saturated moiety receipt the electron into the metallic moiety, which accounts for a reduction potential in the -1.44 to -1.61 range. This situation is maintained in the radical-anions $4 \mathrm{e}^{\cdot-}$, and $4 \mathbf{g}^{\cdot-}$. The LUMO orbital of $4 \mathrm{e}^{\cdot-}$ is still localized across the [FeFe] fragment while radical anion $\mathbf{4 g}^{\cdot-}$ has the LUMO located in the organic moiety, which is easily reducible (still with strong anodic displacements, giving lower reduction potentials than their saturated congeners, due to the presence of the metals). ${ }^{23}$ This proposal nicely explain the "strong effect of the dithiolene and (in their case) tetrachloro-biphenyl dithiolate groups on the level of the LUMO" reported by Gloaguen and Schollhammer. ${ }^{22}$

The electrochemical behavior in acidic media of complexes 4e and $4 \mathbf{g}$ (as representative examples of complexes having either a saturated or double bond in the bridge joining the sulfur atoms) was next studied. None of these complexes showed electrocatalytic behavior in their first reduction wave in the presence of increasing amounts of acetic acid $\left(\mathrm{p} K_{\mathrm{a}} \sim 22.3 \mathrm{in}\right.$ MeCN) ${ }^{24}$ (up to 20 eq., see Fig. 7), while a peak appears around $-1.80 \mathrm{~V}$ which increases its intensity with the concentration of acid. These results are fully consistent with those reported in the literature for related compounds. ${ }^{25}$ It should be noted that

Table 1 Reduction potentials ${ }^{a}$

\begin{tabular}{|c|c|c|c|c|c|c|c|c|c|}
\hline & $E_{\mathrm{pc} 1}$ & $E_{\mathrm{pa} 1}(\Delta E)$ & $E_{(1)}$ & $E_{\mathrm{pc} 2}$ & $E_{\mathrm{pa} 2}(\Delta E)$ & $E_{(2)}$ & $E_{\mathrm{pc} 3}$ & $E_{\mathrm{pa} 3}(\Delta E)$ & $E_{(3)}$ \\
\hline $4 c$ & -1.15 & $-0.96(0.19)$ & -1.06 & -1.59 & - & - & - & - & - \\
\hline 4d & -0.93 & $-0.84(0.09)$ & -0.89 & -1.74 & $-1.64(0.10)$ & - & - & - & - \\
\hline 4f & -0.70 & $-0.60(0.09)$ & -0.65 & -1.47 & - & - & - & - & - \\
\hline $4 \mathrm{~g}$ & -0.46 & $-0.39(0.07)$ & -0.42 & -0.63 & $-0.56(0.07)$ & -0.60 & -1.39 & $-1.30(0.09)$ & -1.34 \\
\hline $4 h$ & -0.40 & $-0.34(0.07)$ & -0.37 & -0.57 & $-0.49(0.08)$ & -0.53 & -1.31 & - & - \\
\hline $4 k$ & -1.11 & $-0.82(0.29)$ & -0.96 & -1.71 & - & - & - & - & - \\
\hline 41 & -1.06 & $-0.91(0.15)$ & -0.99 & -1.83 & - & - & - & - & - \\
\hline $4 m$ & - & - & - & - & - & - & - & - & - \\
\hline $4 n$ & -0.77 & $-0.60(0.18)$ & -0.68 & -1.62 & - & - & - & - & - \\
\hline 40 & -1.10 & $-0.91(0.18)$ & -1.00 & -1.60 & - & - & - & - & - \\
\hline $4 p$ & -1.10 & $-0.99(0.12)$ & -1.04 & -1.50 & - & - & - & - & - \\
\hline
\end{tabular}

${ }^{a}$ Data (V) obtained from $10^{-3} \mathrm{M}$ acetonitrile solutions, containing $0.1 \mathrm{M}\left[N\left({ }^{n} \mathrm{Bu}\right)_{4}\right] \mathrm{PF}_{6}$ as supporting electrolyte at $20^{\circ} \mathrm{C}$. Potentials are relative to Ag/ $\mathrm{AgCl}$. 


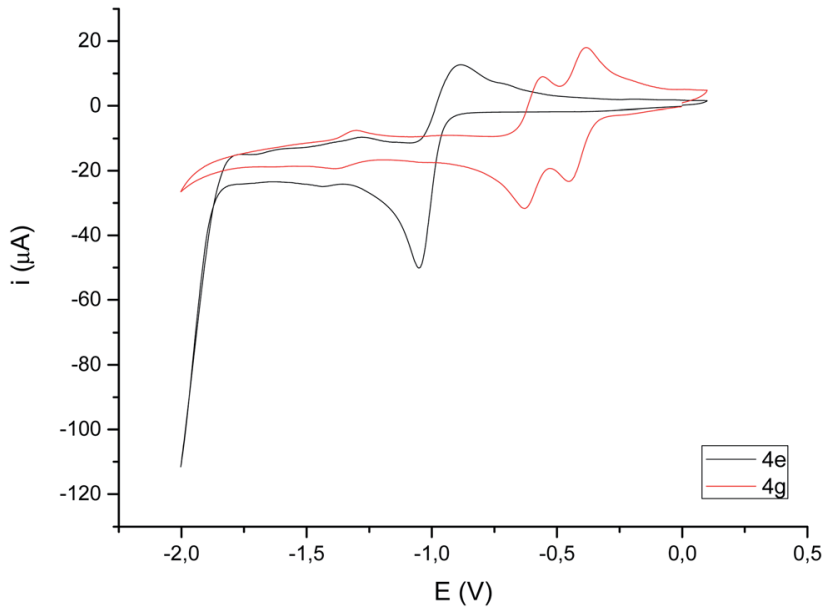

Fig. 5 Cyclic voltammograms (focused on reduction) of compounds $4 \mathrm{e}$ and $4 \mathrm{~g}\left(10^{-3} \mathrm{M}\right.$ in $\left.\mathrm{CH}_{3} \mathrm{CN}\right), 10^{-1} \mathrm{M}\left[\mathrm{N}\left({ }^{n} \mathrm{Bu}\right)_{4}\right] \mathrm{PF}_{6}$, counter-electrode: Pt; working electrode: glassy carbon; reference electrode: $\mathrm{Ag} / \mathrm{AgCl}$; scan rate: $100 \mathrm{mV} \mathrm{s}^{-1}$; values given in $\mathrm{V}$.

the first reduction wave at $-0.42 \mathrm{~V}$ for compound $4 \mathrm{~g}$ (the one attributed to the reduction of the double bond) remains quasireversible, while the second reduction wave at $-0.60 \mathrm{~V}$ losses its quasi-reversibility in the presence of $\mathrm{AcOH}$ as previously reported. ${ }^{22}$

The behavior of complexes $4 \mathbf{e}$ and $\mathbf{4 g}$ towards a stronger acid $\left(\mathrm{CF}_{3} \mathrm{COOH}, \mathrm{p} K_{\mathrm{a}} \sim 12.6 \text { in } \mathrm{MeCN}\right)^{24}$ was next studied. Fig. 8 shows the behavior of these complexes upon increasing additions of $\mathrm{CF}_{3} \mathrm{COOH}$. The reduction of $4 \mathbf{e}$ (Fig. 8, top) becomes irreversible upon addition of less than 1 eq. of $\mathrm{CF}_{3} \mathrm{COOH}$, as reported in the literature for related compounds. ${ }^{26}$ However, the intensity of the reduction wave at $-0.97 \mathrm{~V}$ steadily increases with the concentration of acid and slightly shifts towards more negative values (up to 20 eq. of added $\mathrm{CF}_{3} \mathrm{COOH}$ ). Therefore, the species generated in the electrochemical reduction are able to catalyze the proton reduction. ${ }^{26 a}$ In addition, reduction of protons is also observed around $-1.60 \mathrm{~V}$, even at low acid concentrations (<0.5 eq.).

Complex $4 \mathrm{~g}$ (Fig. 8, bottom) behaves differently. In this case, both waves $(-0.42 \mathrm{~V}$ and $-0.60 \mathrm{~V})$ increase their intensity with the acid concentration until the ratio $4 \mathrm{~g}$ /acid exceeds 4 equivalents. This supports the participation of the double bond in the first reduction event, generating species that are able to catalyze the reduction of protons.

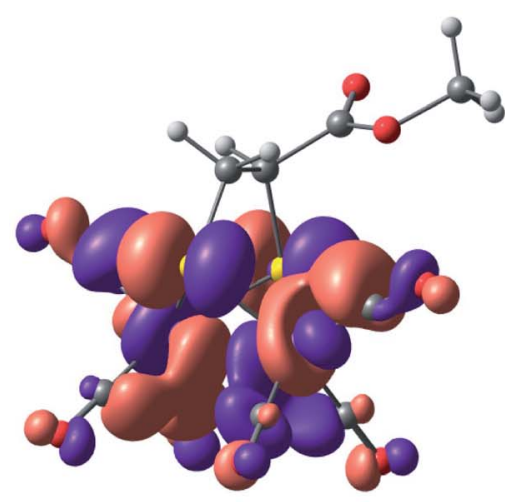

4e LUMO

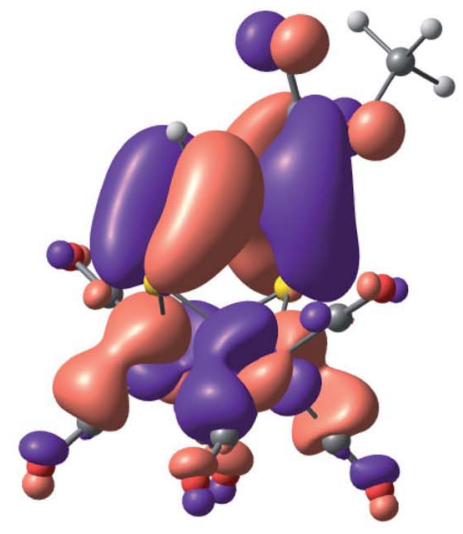

4g LUMO

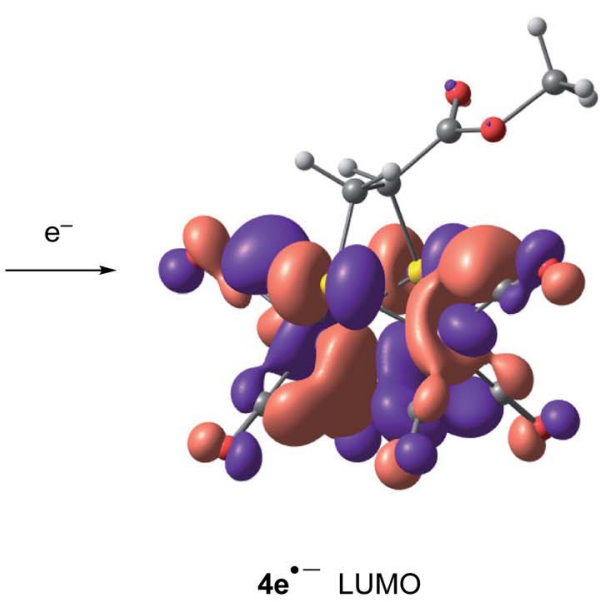

$\mathrm{e}^{-}$

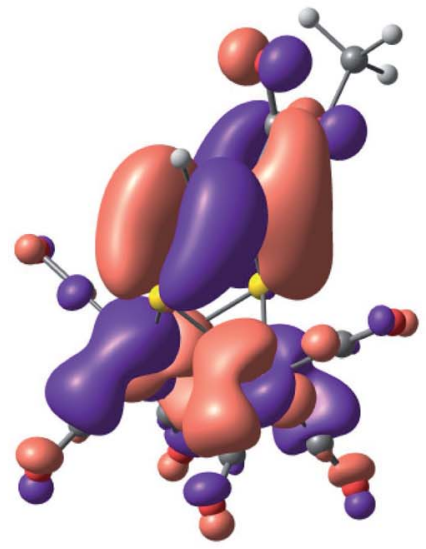

$\mathbf{4 g}^{\bullet-}$ LUMO

Fig. 6 LUMO's of complexes $4 \mathrm{e}, 4 \mathrm{e}^{\cdot-}, 4 \mathrm{~g}$ and $4 \mathrm{~g}^{\cdot-}$. 


\section{Conclusions}

A smooth and efficient photochemical method to prepare functionalized [FeFe]-hydrogenase mimics has been developed. Irradiation of $\left[(\mu-\mathrm{S})_{2} \mathrm{Fe}_{2}(\mathrm{CO})_{6}\right]$ and alkene/alkynes under medium-low CO pressures produce the corresponding photoadducts in good (alkenes) or acceptable yields (alkynes). The formation of photoadducts derived from alkenes occurs with retention of the stereochemistry of the starting olefin, as demonstrated by NOE measurements and X-ray diffraction. The process is compatible with substrates having ferrocene moieties, as well as functional groups like imides and esters. The photocycloaddition occurs through a concerted reaction pathway as demonstrated by extensive DFT-calculations. The stereochemistry of these reactions is compatible with the computed pathway. Alternative reaction pathways involving triplet states are considerable higher in energy, and, for alkynes, predict the formation of products that have not been detected experimentally.

Photoadducts formed from alkynes present a double bond within the metallacycle, that strongly affect the electrochemistry of these compounds. Thus, in the presence of this double bond two strongly anodic displaced quasi-reversible reduction waves appear. These reduction events are compatible with the one electron ${ }^{17}$ reduction of the double bond "conjugated" with the [FeFe]-moiety. This one electron reduction, forms a radicalanion with a formal $\left[\mathrm{Fe}^{0} \mathrm{Fe}^{\mathrm{I}}\right]$ state, which facilitate the second reduction to form the $\left[\mathrm{Fe}^{0} \mathrm{Fe}^{0}\right]$ state.

The electrochemistry of complexes 4 in the presence of acids reveals a different behaviour between complexes having a double bond in the dithiametallacycle and those lacking this insaturation. Thus, complexes lacking the insaturation in the metallacycle behave like the analogous products reported in the literature. For this compounds, in the presence of soft acids $(\mathrm{AcOH})$ the species derived from the quasi-reversible reduction wave around $-0.97 \mathrm{~V}$ are electrocatalytically inactive, and a new electrocatalytically active band appears at $-1.80 \mathrm{~V}$. Complexes 4 having a double bond in the metallacycle behave similarly towards soft acids. However, in the presence of strong acids $\left(\mathrm{CF}_{3} \mathrm{COOH}\right)$ the species formed upon reduction in the wave around $-0.97 \mathrm{~V}$ are able to reduce protons. For these unsaturated complexes, a new reduction wave appears around $-1.60 \mathrm{~V}$ that is also catalytically active. Therefore, for complexes having a double bond, both waves $(-0.42 \mathrm{~V}$ and $-0.60 \mathrm{~V})$ become

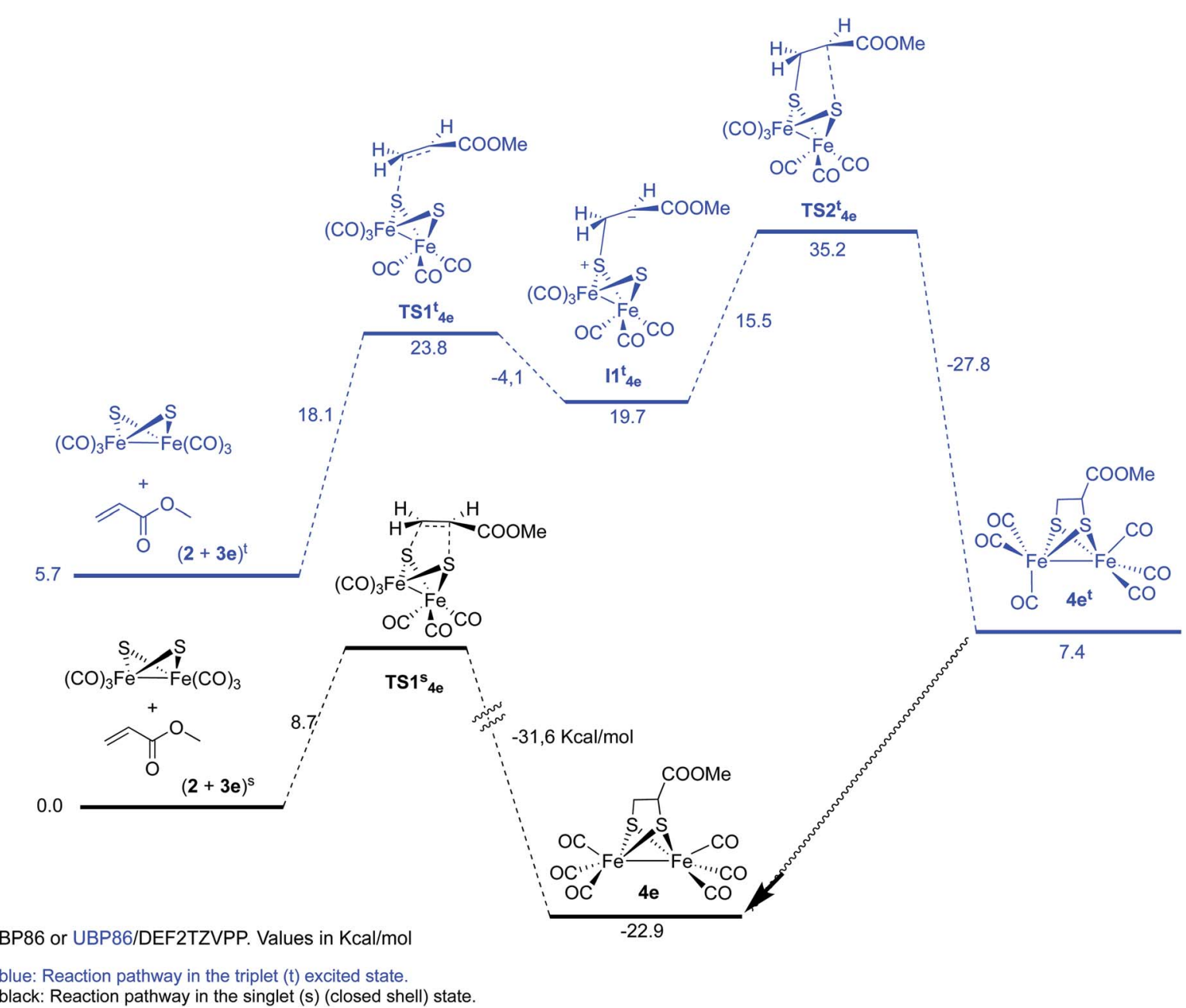

Scheme 8 Reaction of complex 2 with methyl acrylate $3 \mathrm{e}$. 
catalytically active, showing the participation of dithiolene ligand in its structure.

Further work to apply these smooth methodologies to prepare more sophisticated [FeFe]-mimics, together with post functionalization of the photoadducts, is now underway in our laboratories.

\section{Experimental section}

\section{General}

Flame-dried glassware was used for moisture-sensitive reactions, and anhydrous solvents were taken from a Pure Solvent PS-MD-5 apparatus. Silica gel (Merck: 230-400 mesh) was used as stationary phase for purification of crude reaction mixtures by flash column chromatography. NMR spectra were recorded at $25{ }^{\circ} \mathrm{C}$ in DMSO- $d_{6}$ or $\mathrm{CDCl}_{3}$ on a 300 and $500 \mathrm{MHz}$ spectrometers. IR spectra were taken on a MIR (8000-400 $\left.\mathrm{cm}^{-1}\right)$
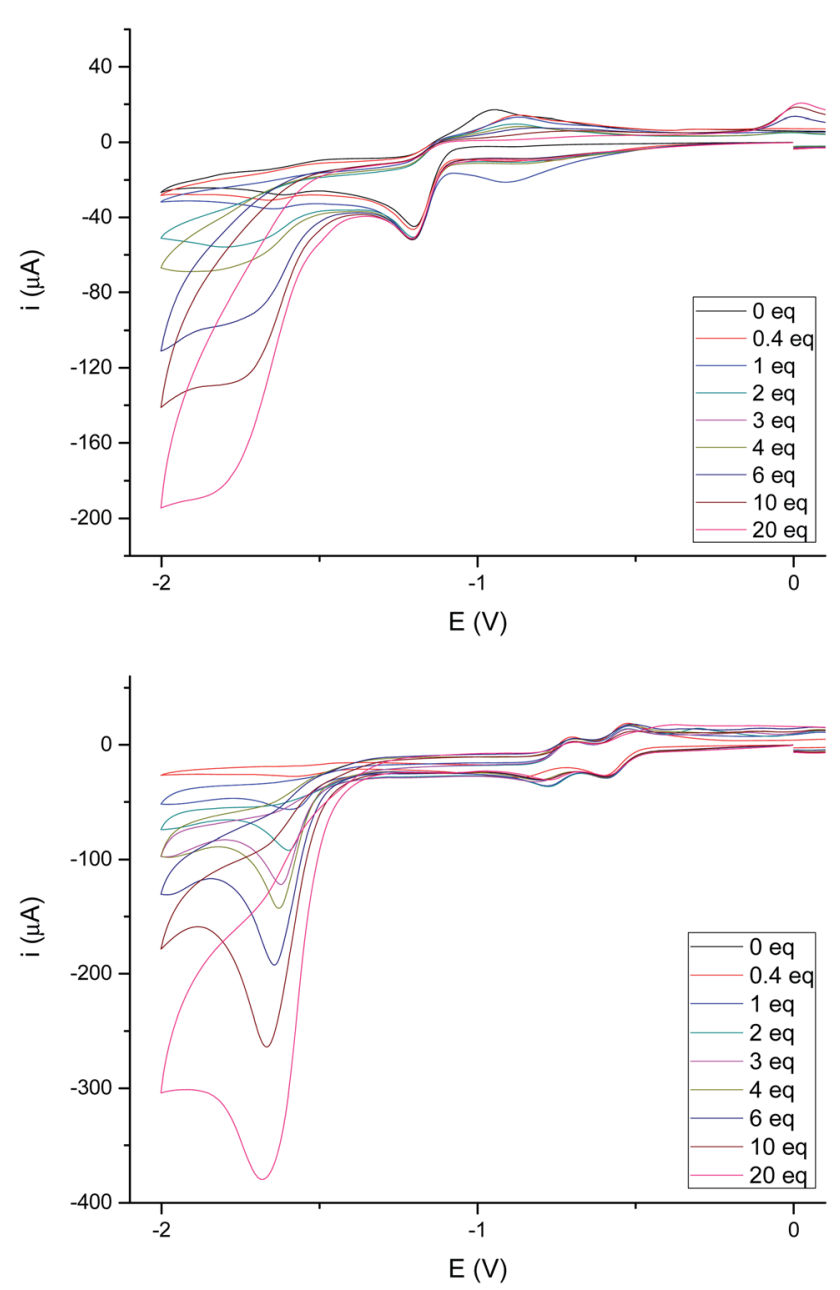

Fig. 7 (Top) Cyclic voltammograms of $4 \mathrm{e}$ with added HOAc $(0-20$ eq.). Data $(\mathrm{V})$ obtained from $10^{-3} \mathrm{M}$ acetonitrile solutions, containing $0.1 \mathrm{M}\left[\mathrm{N}\left({ }^{n} \mathrm{Bu}\right)_{4}\right] \mathrm{PF}_{6}$ as supporting electrolyte at $20{ }^{\circ} \mathrm{C}$. Potentials are relative to $\mathrm{Ag} / \mathrm{AgCl}$. (Bottom) Cyclic voltammograms of $4 \mathrm{~g}$ with added HOAC (0-20 eq.). Data (V) obtained from $10^{-3} \mathrm{M}$ acetonitrile solutions, containing $0.1 \mathrm{M}\left[\mathrm{N}\left({ }^{n} \mathrm{Bu}\right)_{4}\right] \mathrm{PF}_{6}$ as supporting electrolyte at $20{ }^{\circ} \mathrm{C}$. Potentials are relative to $\mathrm{Ag} / \mathrm{AgCl}$. spectrometer using the attenuated total reflectance (ATR) technique. HRMS experiments were recorded on an Agilent 6500 accurate mass apparatus with a Q-TOF analyzer. Cyclic voltammograms were recorded using a Metrohm Autolab Potentiostat model PGSTAT302N with a glassy carbon working electrode, $\mathrm{Ag} / \mathrm{AgCl} 3 \mathrm{M}$ as reference and a $\mathrm{Pt}$ wire counter electrode. All the measurements were performed under Ar, at room temperature from $\mathrm{CH}_{3} \mathrm{CN}$ solutions containing $0.1 \mathrm{M}$ $\left[\mathrm{N}^{n} \mathrm{Bu}_{4}\right] \mathrm{PF}_{6}$ as supporting electrolyte, with analyte concentrations of $1 \mathrm{mM}$ (scan rate $0.1 \mathrm{~V} \mathrm{~s}^{-1}$ ). When needed, an ultrasound bath was used to promote solubilization in those samples were a suspension was initially obtained.

\section{Computational details}

Theoretical calculations have been performed using the Gaussian 09-D.01 software package ${ }^{27}$ at the BP86/Def2tzvpp ${ }^{28}$
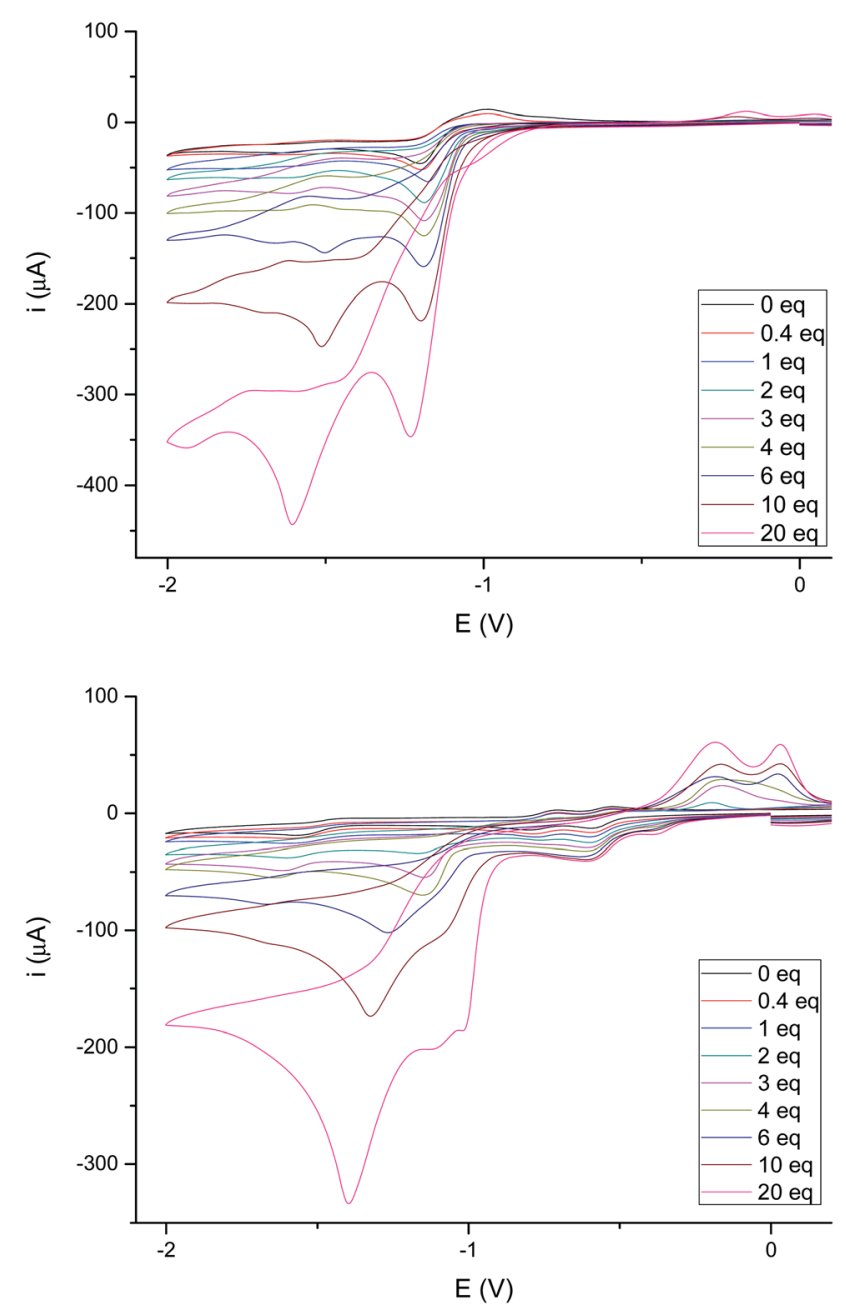

Fig. 8 (Top) Cyclic voltammograms of 4 e with added TFA (0-20 eq. of $\left.\mathrm{H}^{+}\right)$. Data (V) obtained from $10^{-3} \mathrm{M}$ acetonitrile solutions, containing $0.1 \mathrm{M}\left[\mathrm{N}\left({ }^{n} \mathrm{Bu}\right)_{4}\right] \mathrm{PF}_{6}$ as supporting electrolyte at $20{ }^{\circ} \mathrm{C}$. Potentials are relative to $\mathrm{Ag} / \mathrm{AgCl}$. (Bottom) Cyclic voltammograms of $4 \mathrm{~g}$ with added TFA $\left(0-20\right.$ eq. of $\left.\mathrm{H}^{+}\right)$. Data $(\mathrm{V})$ obtained from $10^{-3} \mathrm{M}$ acetonitrile solutions, containing $0.1 \mathrm{M}\left[N\left({ }^{n} \mathrm{Bu}\right)_{4}\right] \mathrm{PF}_{6}$ as supporting electrolyte at $20{ }^{\circ} \mathrm{C}$. Potentials are relative to $\mathrm{Ag} / \mathrm{AgCl}$. 
level for all atoms. A SCRF, $\mathrm{CPCM}^{29}$ solvent model for THF was also used. Compounds $\mathbf{4 e}, \mathbf{4 g}$ and their corresponding radical anions were also calculated using $\mathrm{MeCN}$ as solvent in order to match the conditions used in the electrochemical experiments An ultrafine-grid was used as integration grid for all the calculations as implemented in the G09 software suite.

\section{General procedure for the synthesis of [FeFe]-hydrogenase mimics}

Photochemical reactions. Photochemical reactions were conducted by using a $125 \mathrm{~W}$ or $400 \mathrm{~W}$-medium pressure mercury lamp through a pyrex filter/pyrex well. Starting materials were dissolved in dry and degassed (vacuum-Ar, four cycles) THF in a rubber septum-sealed Pyrex tube purged with argon. In a typical experiment, an equimolecular solution of $[(\mu-$ $\left.\mathrm{S})_{2} \mathrm{Fe}_{2}(\mathrm{CO})_{6}\right] 2$ and the corresponding alkene or alkyne in dry THF (200 mL mmol ${ }^{-1}$ ) was bubbled with CO for 5 minutes and was irradiated overnight under CO pressure (1 atm, balloon). The solvent was then removed under reduced pressure, and the product was purified by $\mathrm{SiO}_{2}$ column chromatography.

Synthesis of 4c. Following the general procedure, a solution of bimetallic complex 2 (200 mg, $0.58 \mathrm{mmol})$ and 1-hexene 3c ( $49 \mathrm{mg}, 0.58 \mathrm{mmol}$ ) in $100 \mathrm{~mL}$ of THF was irradiated ( $125 \mathrm{~W}$ ) for 15 h. Purification by $\mathrm{SiO}_{2}$ chromatography (Hex/EtOAc $8: 2$ ) yielded pure $4 \mathrm{c}(159 \mathrm{mg}, 64 \%)$ as a dark red solid. ${ }^{1} \mathrm{H}$ NMR $(300$ $\left.\mathrm{MHz}, \mathrm{CDCl}_{3}\right) \delta 0,90\left(\mathrm{t}, 3 \mathrm{H}, J=6.9 \mathrm{~Hz}, \mathrm{CH}_{3}\right), 1.25-1.57(\mathrm{~m}, 6 \mathrm{H}, 3 \times$ $\mathrm{CH}_{2}$ ), 1.80 (dd, $\left.1 \mathrm{H}, J=12.3,4.8 \mathrm{~Hz}, \mathrm{CH}\right), 2.57-2.73\left(\mathrm{~m}, 2 \mathrm{H}, \mathrm{CH}_{2}\right.$ ). ${ }^{13} \mathrm{C}$ NMR (75 MHz, $\mathrm{CDCl}_{3}$ ) $\delta$ 208.7, 54.6, 42.2, 36.9, 31.8, 22.6, 14.0. IR (film): $\nu$ 2962, 2931, 2863, 2074, 2029, $1976 \mathrm{~cm}^{-1}$. Anal. calcd for $\mathrm{C}_{12} \mathrm{H}_{12} \mathrm{Fe}_{2} \mathrm{O}_{6} \mathrm{~S}_{2}$ : C, 33.67; H, 2.83; S, 14.98. Found C, 33.59; H, 2.91; S, 15.21.

Synthesis of $4 d$. Following the general procedure, a solution of bimetallic complex 2 (200 mg, $0.58 \mathrm{mmol}$ ) and $N$-phenylmaleimide 3d (101 mg, $0.58 \mathrm{mmol}$ ) in $100 \mathrm{~mL}$ of THF was irradiated $(125 \mathrm{~W})$ for $15 \mathrm{~h}$. Purification by $\mathrm{SiO}_{2}$ chromatography (Hex/EtOAc $7: 3)$ yielded pure $4 d(211 \mathrm{mg}, 70 \%)$ as an orange solid. ${ }^{1} \mathrm{H}$ NMR $\left(300 \mathrm{MHz}, \mathrm{CDCl}_{3}\right) \delta 3.92(\mathrm{~s}, 2 \mathrm{H}, 2 \times \mathrm{CH})$, 7.25-7.34 (m, 2H, Ar), 7.38-7.51 (m, 3H, Ar). ${ }^{13} \mathrm{C}$ NMR (75 MHz, $\left.\mathrm{CDCl}_{3}\right) \delta 206.5,169.9,130.7,129.1,129.0,125.7,54.3$. IR (film): $\nu$ 2925, 2854, 2083, 2043, 1998, 1717, 1374, $1184 \mathrm{~cm}^{-1}$. ESI-HRMS $m / z$ calcd for $\mathrm{C}_{16} \mathrm{H}_{7} \mathrm{Fe}_{2} \mathrm{NNaO}_{8} \mathrm{~S}_{2}[\mathrm{M}+\mathrm{Na}]^{+}$539.82047; found 539.82269.

Synthesis of 4e. Following the general procedure, a solution of bimetallic complex $2(200 \mathrm{mg}, 0.58 \mathrm{mmol})$ and methyl acrylate $3 \mathrm{e}(50 \mathrm{mg}, 0.58 \mathrm{mmol})$ in $100 \mathrm{~mL}$ of THF was irradiated (125 W) for $15 \mathrm{~h}$. Purification by $\mathrm{SiO}_{2}$ chromatography (Hex/EtOAc $8: 2)$ yielded pure 4 e $(95 \mathrm{mg}, 86 \%)$ as a red solid. ${ }^{1} \mathrm{H}$ NMR $\left(300 \mathrm{MHz}, \mathrm{CDCl}_{3}\right) \delta 2.57-2.53\left(\mathrm{~m}, 2 \mathrm{H}, \mathrm{CH}_{2}\right), 3.28-3.32(\mathrm{~m}, 1 \mathrm{H}$, $\mathrm{CH}), 3.77\left(\mathrm{~s}, 3 \mathrm{H}, \mathrm{CH}_{3}\right) .{ }^{13} \mathrm{C} \mathrm{NMR}\left(75 \mathrm{MHz}, \mathrm{CDCl}_{3}\right) \delta 207.8,170.2$, 53.3, 52.8, 38.8. IR (film): $\nu$ 2078, 2034, 1983, $1737 \mathrm{~cm}^{-1}$. Anal. calcd for $\mathrm{C}_{10} \mathrm{H}_{6} \mathrm{Fe}_{2} \mathrm{O}_{8} \mathrm{~S}_{2}$ : C, 27.94; $\mathrm{H}, 1.41 ; \mathrm{S}, 14.91$. Found $\mathrm{C}$, 28.30; H, 1.77; S, 14.85 .

Synthesis of $4 \mathrm{f}$. Following the general procedure, a solution of bimetallic complex 2 (200 $\mathrm{mg}, 0.58 \mathrm{mmol}$ ) and 4-ethynyltoluene $3 \mathrm{f}$ (68 $\mathrm{mg}, 0.58 \mathrm{mmol}$ ) in $100 \mathrm{~mL}$ of THF was irradiated $(125 \mathrm{~W})$ for $15 \mathrm{~h}$. Purification by $\mathrm{SiO}_{2}$ chromatography (Hex/
EtOAc $8: 2)$ yielded pure $4 \mathbf{f}(120 \mathrm{mg}, 45 \%)$ as a red-orange solid. ${ }^{1} \mathrm{H}$ NMR $\left(300 \mathrm{MHz}, \mathrm{CDCl}_{3}\right) \delta 2.31\left(\mathrm{~s}, 1 \mathrm{H}, \mathrm{CH}_{3}\right), 6.35(\mathrm{~s}$, $1 \mathrm{H}, \mathrm{CHS}$ ), 7.09 (d, 2H, $J=8.2 \mathrm{~Hz}, \mathrm{Ar}$ ), 7.21 (d, 2H, $J=8.2 \mathrm{~Hz}, \mathrm{Ar}$ ). ${ }^{13} \mathrm{C}$ NMR (75 MHz, $\mathrm{CDCl}_{3}$ ) $\delta$ 207.7, 161.8, 140.1, 133.1, 130.7, 129.4, 125.2, 21.5. IR (film): $\nu 2074,2029,1976 \mathrm{~cm}^{-1}$. Anal. calcd for $\mathrm{C}_{15} \mathrm{H}_{8} \mathrm{Fe}_{2} \mathrm{O}_{6} \mathrm{~S}_{2}$ : C, 39.16; $\mathrm{H}, 1.75 ; \mathrm{S}, 13.94$. Found $\mathrm{C}, 39.04 ; \mathrm{H}$, $1.88 ; \mathrm{S}, 13.75$.

Synthesis of $4 \mathrm{~g}$. Following the general procedure, a solution of bimetallic complex 2 (200 mg, $0.58 \mathrm{mmol}$ ) and Methyl propiolate $3 \mathrm{~g}$ ( $49 \mathrm{mg}, 0.58 \mathrm{mmol}$ ) in $100 \mathrm{~mL}$ of THF was irradiated $(125 \mathrm{~W})$ for $15 \mathrm{~h}$. Purification by $\mathrm{SiO}_{2}$ chromatography (Hex/ EtOAc $9: 1)$ yielded pure $4 \mathrm{~g}(95 \mathrm{mg}, 38 \%)$ as a red solid. ${ }^{1} \mathrm{H}$ $\mathrm{NMR}\left(300 \mathrm{MHz}, \mathrm{CDCl}_{3}\right) \delta 3.68\left(\mathrm{~s}, 3 \mathrm{H}, \mathrm{CH}_{3}\right), 7.37(\mathrm{~s}, 1 \mathrm{H}, \mathrm{CH}) .{ }^{13} \mathrm{C}$ NMR (75 MHz, $\left.\mathrm{CDCl}_{3}\right) \delta$ 206.2, 160.8, 157.6, 153.1, 52.2. IR (film): $\nu$ 2080, 2041, 1994, 1719, $1253 \mathrm{~cm}^{-1}$. ESI-HRMS $\mathrm{m} / z$ calcd for $\mathrm{C}_{10} \mathrm{H}_{4} \mathrm{Fe}_{2} \mathrm{NaO}_{8} \mathrm{~S}_{2}[\mathrm{M}+\mathrm{Na}]^{+}$450.79390; found 450.79282 .

Synthesis of $4 \mathbf{h}$. Following the general procedure, a solution of bimetallic complex 2 (200 $\mathrm{mg}, 0.58 \mathrm{mmol})$ and dimethyl acetylenedicarboxylate $3 \mathbf{h}$ ( $83 \mathrm{mg}, 0.58 \mathrm{mmol})$ in $100 \mathrm{~mL}$ of THF was irradiated $(125 \mathrm{~W})$ for $15 \mathrm{~h}$. Purification by $\mathrm{SiO}_{2}$ chromatography (Hex/EtOAc $8: 2)$ yielded pure $4 \mathbf{h}(176 \mathrm{mg}, 62 \%)$ as a red solid. ${ }^{1} \mathrm{H}$ NMR $\left(300 \mathrm{MHz}, \mathrm{CDCl}_{3}\right) \delta 3.72\left(\mathrm{~s}, 6 \mathrm{H}, 2 \times \mathrm{CH}_{3}\right)$. ${ }^{13} \mathrm{C} \mathrm{NMR}\left(75 \mathrm{MHz} \mathrm{CDCl}_{3}\right) \delta 206.9,162.3,155.5,53.3$. IR (film): $\nu$ 2086, 2050, 2008, 1728, $1255 \mathrm{~cm}^{-1}$. ESI-HRMS $\mathrm{m} / z$ calcd for $\mathrm{C}_{12} \mathrm{H}_{7} \mathrm{Fe}_{2} \mathrm{O}_{10} \mathrm{~S}_{2}[\mathrm{M}+\mathrm{H}]^{+}$486.81744; found 486.81522 .

Synthesis of $4 \mathbf{i}$. Following the general procedure, a solution of bimetallic complex $2(200 \mathrm{mg}, 0.58 \mathrm{mmol})$ and methyl trans-2ferrocenylacrylate $3 \mathbf{i}(157 \mathrm{mg}, 0.58 \mathrm{mmol}$ ) in $100 \mathrm{~mL}$ of THF was irradiated (125 W) for $15 \mathrm{~h}$. Purification by $\mathrm{SiO}_{2}$ chromatography (Hex/EtOAc $8: 2)$ yielded pure $4 \mathbf{i}(155 \mathrm{mg}, 43 \%)$ as a red solid. ${ }^{1} \mathrm{H}$ NMR $\left(300 \mathrm{MHz}, \mathrm{CDCl}_{3}\right) \delta 3.16(\mathrm{~d}, 1 \mathrm{H}, J=6.3 \mathrm{~Hz}$, $\mathrm{CHCO}$ ), 3.86 (s, 3H, $\mathrm{OCH}_{3}$ ), 3.98 (bs, 1H, Cp), 4.08 (s, 5H, Cp), 4.13 (d, $1 \mathrm{H}, J=6.3 \mathrm{~Hz}, \mathrm{CH}-\mathrm{Cp}), 4.21-4.28$ (m, 3H, Cp). ${ }^{13} \mathrm{C} \mathrm{NMR}$ $\left(300 \mathrm{MHz}, \mathrm{CDCl}_{3}\right) \delta$ 208.0, 170.9, 84.9, 69.5, 69.1, 68.9, 68.7, 65.4, 56.9, 56.0, 53.40. IR (film): $\nu$ 2075, 2033, 1980, 1735, $1266 \mathrm{~cm}^{-1}$. ESI-HRMS $\mathrm{m} / z$ calcd for $\mathrm{C}_{20} \mathrm{H}_{15} \mathrm{Fe}_{3} \mathrm{O}_{8} \mathrm{~S}_{2}[\mathrm{M}+\mathrm{H}]^{+}$ 614.82522; found 614.82740 .

Synthesis of $\mathbf{4 j}$. Following the general procedure, a solution of bimetallic complex 2 (113 mg, $0.33 \mathrm{mmol})$ and ethynylpurine derivative $3 \mathbf{j}$ (133 mg, $0.33 \mathrm{mmol}$ ) in $100 \mathrm{~mL}$ of THF was irradiated $(125 \mathrm{~W})$ for $15 \mathrm{~h}$. Purification by $\mathrm{SiO}_{2}$ chromatography (Hex/EtOAc $4: 6$ ) yielded pure $4 \mathbf{j}(59 \mathrm{mg}, 24 \%)$ as a red solid. ${ }^{1} \mathrm{H}$ NMR (500 MHz, $\left.\mathrm{CDCl}_{3}\right) \delta 2.07\left(\mathrm{~s}, 3 \mathrm{H}, \mathrm{CH}_{3}\right), 2.10\left(\mathrm{~s}, 3 \mathrm{H}, \mathrm{CH}_{3}\right)$, $2.15\left(\mathrm{~s}, 3 \mathrm{H}, \mathrm{CH}_{3}\right), 4.34-4.46(\mathrm{~m}, 3 \mathrm{H}, 3 \times \mathrm{CH}-\mathrm{O}), 5.63(\mathrm{t}, 1 \mathrm{H}, J=$ $5.2 \mathrm{~Hz}, \mathrm{CH}), 5.92(\mathrm{t}, 1 \mathrm{H}, J=5.2 \mathrm{~Hz}, \mathrm{CH}), 6.20(\mathrm{~d}, 1 \mathrm{H}, J=5.2 \mathrm{~Hz}$, $\mathrm{CH}), 8.15(\mathrm{~s}, 1 \mathrm{H}, \mathrm{Ar}), 8.46(\mathrm{~s}, 1 \mathrm{H},=\mathrm{CH}), 8.97$ (s, $1 \mathrm{H}, \mathrm{Ar}) .{ }^{13} \mathrm{C}$ NMR (125 MHz, $\left.\mathrm{CDCl}_{3}\right) \delta$ 207.4, 170.4, 169.7, 169.5, 157.5, 154,7, 152.6, 150.9, 148.9, 143.3, 130.2, 86.7, 80.6, 73.2, 70.6, 63.0, 20.9, 20.7, 20.5. IR (film): $\nu$ 2079, 2042, 2000, 1751, 1577, $1224 \mathrm{~cm}^{-1}$. ESI-HRMS $m / z$ calcd for $\mathrm{C}_{24} \mathrm{H}_{19} \mathrm{Fe}_{2} \mathrm{~N}_{4} \mathrm{O}_{13} \mathrm{~S}_{2}[\mathrm{M}+\mathrm{H}]^{+} 746.90844$; found 746.91145 .

Synthesis of $4 \mathbf{k}$. Following the general procedure, a solution of bimetallic complex $2(200 \mathrm{mg}, 0.58 \mathrm{mmol})$ and $N, N^{\prime}-(1,4-$ phenylene)dimaleimide $3 \mathbf{k}(117 \mathrm{mg}, 0.58 \mathrm{mmol})$ in $100 \mathrm{~mL}$ of THF was irradiated $(125 \mathrm{~W})$ for $15 \mathrm{~h}$. Purification by $\mathrm{SiO}_{2}$ chromatography (Hex/EtOAc $8: 2$ ) yielded pure 4k (107 mg, $26 \%$ ) as a reddish solid. ${ }^{1} \mathrm{H}$ NMR (300 MHz, DMSO- $\left.d_{6}\right) \delta 4.48$ (s, 
$4 \mathrm{H}, \mathrm{CH}), 7.39$ (s, 4H, Ar), ${ }^{13} \mathrm{C} \mathrm{NMR}\left(75 \mathrm{MHz}, \mathrm{CDCl}_{3}\right) \delta$ 182.0, 170.4, 130.6, 126.4, 54.2. IR (film): $\nu$ 2080, 2039, 2008, 1979, $1781,1708 \mathrm{~cm}^{-1}$. ESI-HRMS $\mathrm{m} / z$ calcd for $\mathrm{C}_{26} \mathrm{H}_{12} \mathrm{Fe}_{4} \mathrm{~N}_{3} \mathrm{O}_{16} \mathrm{~S}_{4}[\mathrm{M}$ $\left.+\mathrm{NH}_{4}\right]^{+}$973.64953; found 973.64842.

Synthesis of 41 and $4 \mathrm{~m}$. Following the general procedure, a solution of bimetallic complex $2(319 \mathrm{mg}, 0.93 \mathrm{mmol})$ and $(E, E)-1,1^{\prime}$-bis-[ $\beta$-(methoxycarbonyl)ethenyl]ferrocene 31 (150 mg, $0.42 \mathrm{mmol})$ in $100 \mathrm{~mL}$ of THF was irradiated $(125 \mathrm{~W})$ for $15 \mathrm{~h}$. Purification by $\mathrm{SiO}_{2}$ chromatography (Hex/EtOAc $7: 3$ ) yielded $153 \mathrm{mg}$ (35\%) of pure complex 4l. Pure complex 4m (154 mg, $52 \%)$ was also isolated.

Complex $4 \mathrm{l}$ (35\%). ${ }^{1} \mathrm{H}$ NMR (300 MHz, $\left.\mathrm{CDCl}_{3}\right) \delta 3.04$ (d, $1 \mathrm{H}, J$ $=6.1 \mathrm{~Hz}, \mathrm{CHCO}), 3.77\left(\mathrm{~s}, 3 \mathrm{H}, \mathrm{OCH}_{3}\right), 3.87\left(\mathrm{~s}, 3 \mathrm{H}, \mathrm{OCH}_{3}\right), 3.95(\mathrm{~s}$, $1 \mathrm{H}, \mathrm{Cp}), 4.03$ (d, 1H, $J=6.1 \mathrm{~Hz}, \mathrm{CHS}), 4.14-4.49$ (m, 7H, Cp), $6.03(\mathrm{~d}, 1 \mathrm{H}, J=15.8 \mathrm{~Hz}, \mathrm{CH}), 7.49$ (d, $1 \mathrm{H}, J=15.8 \mathrm{~Hz}, \mathrm{CH}) .{ }^{13} \mathrm{C}$ NMR (300 MHz, $\left.\mathrm{CDCl}_{3}\right) \delta 207.9,170.6,167.4,144.6,115.9,86.5$, 79.8, 72.0, 71.9, 71.4, 70.7, 69.7, 69.4, 67.0, 56.5, 55.9, 53.5, 51.6. IR (film): $\nu$ 2075, 2034, 1976, 1723(sh), 1701, 1629, 1435, 1264, $1195,1157 \mathrm{~cm}^{-1}$. ESI-HRMS $m / z$ calcd for $\mathrm{C}_{24} \mathrm{H}_{19} \mathrm{Fe}_{3} \mathrm{O}_{10} \mathrm{~S}_{2}[\mathrm{M}+$ $\mathrm{H}]^{+}$698.84638; found 698.84799 .

Complex $4 m$ (52\%). ${ }^{1} \mathrm{H} \mathrm{NMR}\left(300 \mathrm{MHz}, \mathrm{CDCl}_{3}\right) \delta 3.09(\mathrm{~d}, 1 \mathrm{H}, J$ $=6 \mathrm{~Hz}, \mathrm{CHCO}), 3.11(\mathrm{~d}, 1 \mathrm{H}, J=6 \mathrm{~Hz}, \mathrm{CHCO}), 3.86(\mathrm{~s}, 3 \mathrm{H}$, $\mathrm{OCH}_{3}$ ), 3.87-3.91 (m, 2H, Cp), 3.89 (s, 3H, $\mathrm{OCH}_{3}$ ), 4.03-4.08 (m, $3 \mathrm{H}, \mathrm{CHS}, \mathrm{Cp}), 4.12-4.20$ (m, 5H, Cp). ${ }^{13} \mathrm{C} \mathrm{NMR} \mathrm{(300} \mathrm{MHz,} \mathrm{CDCl}_{3}$ ) $\delta 208.5,170.8,170.8,86.1,86.0,70.7,70.4,70.1,70.1,69.7,69.5$, 66.5, 65.6, 56.2, 56.1, 55.8, 53.6, 53.5. IR (film): $\nu$ 2075, 2034, 1976, 1701, 1629, 1434, 1306, 1263, $1194 \mathrm{~cm}^{-1}$. ESI-HRMS $\mathrm{m} / z$ calcd for $\mathrm{C}_{30} \mathrm{H}_{18} \mathrm{Fe}_{5} \mathrm{NaO}_{16} \mathrm{~S}_{4}[\mathrm{M}+\mathrm{Na}]^{+}$1064.61211; found 1064.60748.

Synthesis of $4 n$. Following the general procedure, a solution of bimetallic complex 2 (331 $\mathrm{mg}, 0.97 \mathrm{mmol})$ and 1,3-bis(2propynyloxy)benzene $3 \mathrm{n}$ ( $80 \mathrm{mg}, 0.44 \mathrm{mmol}$ ) in $100 \mathrm{~mL}$ of THF was irradiated $(400 \mathrm{~W})$ for $15 \mathrm{~h}$. Purification by $\mathrm{SiO}_{2}$ chromatography (Hex/EtOAc $9: 1)$ yielded pure $4 \mathbf{n}(40 \mathrm{mg}, 17 \%)$ as a red solid. ${ }^{1} \mathrm{H}$ NMR $\left(300 \mathrm{MHz}, \mathrm{CDCl}_{3}\right) \delta 2.53(\mathrm{t}, 1 \mathrm{H}, J=$ $2.4 \mathrm{~Hz}, \equiv \mathrm{CH}), 4.21$ (d, $\left.2 \mathrm{H}, J=1.9 \mathrm{~Hz}, \mathrm{OCH}_{2}\right), 4.66(\mathrm{~d}, 2 \mathrm{H}, J=$ $\left.2.4 \mathrm{~Hz}, \equiv \mathrm{C}-\mathrm{CH}_{2} \mathrm{O}\right), 6.23(\mathrm{t}, 1 \mathrm{H}, J=1.9 \mathrm{~Hz},=\mathrm{CH}), 6.37-6.41(\mathrm{~m}$, 2H, Ar), 6.59-6.62 (m, 1H, Ar), 7.18 (dd, 1H, $J=9.2,7.4 \mathrm{~Hz}, \mathrm{Ar}$ ). ${ }^{13} \mathrm{C}$ NMR $\left(75 \mathrm{MHz}, \mathrm{CDCl}_{3}\right) \delta 207.5,158.9,158.7,158.6,158.3$, 138.8, 130.2, 108.1, 107.6, 102.5, 75.8, 66.6, 56.0. IR (film): $\nu$ 2074, 2030, 1970, 1886, 1502, $1208 \mathrm{~cm}^{-1}$. Anal. calcd for $\mathrm{C}_{18} \mathrm{H}_{10} \mathrm{Fe}_{2} \mathrm{O}_{8} \mathrm{~S}_{2}$ : C, 40.79; H, 1.90; S, 12.10. Found, C, 40.43; H, $2.14 ; \mathrm{S}, 12.54$.

Synthesis of complexes 40 and $4 p$. Following the general procedure, a solution of bimetallic complex 2 (198 mg, 0.58 $\mathrm{mmol}$ ) and 1,4-bis(prop-2-yn-1-yloxy)benzene 30 (50 mg, 0.26 $\mathrm{mmol}$ ) in $100 \mathrm{~mL}$ of THF was irradiated (125 W) for $15 \mathrm{~h}$. Purification by $\mathrm{SiO}_{2}$ chromatography (Hex/EtOAc $20: 1$ ) yielded $77 \mathrm{mg}(55 \%)$ of pure 40 and $46 \mathrm{mg}$ (20\%) of pure $4 \mathbf{p}$ as red solids.

Complex 4 o (55\%). ${ }^{1} \mathrm{H}$ NMR $\left(300 \mathrm{MHz}, \mathrm{CDCl}_{3}\right) \delta 2.10(\mathrm{dd}, 1 \mathrm{H}, J$ $\left.=13.2,5.5 \mathrm{~Hz}, \mathrm{CH}_{2} \mathrm{~S}\right), 2.75\left(\mathrm{dd}, 1 \mathrm{H}, J=13.2,7.4 \mathrm{~Hz}, \mathrm{CH}_{2} \mathrm{~S}\right), 2.98-$ 3.06 (m, 1H, CHS), 3.79 (dd, $1 \mathrm{H}, J=9.7,7.0 \mathrm{~Hz}, \mathrm{SCHCH}_{2}$ ), 3.97 (dd, $1 \mathrm{H}, J=9.7,5.8 \mathrm{~Hz}, \mathrm{SCHCH}_{2}$ ), 4.49 (bd, $2 \mathrm{H}, J=5.4 \mathrm{~Hz}$, $\left.\mathrm{C}_{2} \mathrm{CH}=\right), 5.27\left(\mathrm{~d}, 1 \mathrm{H}, J=10.5 \mathrm{~Hz},=\mathrm{CH}_{2}\right), 5.39$ (d, $1 \mathrm{H}, J=$ $16.1 \mathrm{~Hz},=\mathrm{CH}_{2}$ ), 6.04 (ddt, $1 \mathrm{H}, J=16.1,10.5,5.4 \mathrm{~Hz}, \mathrm{CH}=$ ), 6.74-6.91 (m, 4H, Ar). ${ }^{13} \mathrm{C}$ NMR (75 MHz, $\mathrm{CDCl}_{3}$ ) $\delta$ 208.4, 153.5,
152.3, 133.50, 117.8, 115.9, 115.7, 70.8, 69.6, 52.7, 39.1. IR (film): $\nu$ 2074, 2029, 1969, 1885, 1502, $1208 \mathrm{~cm}^{-1}$. Anal. calcd for $\mathrm{C}_{18} \mathrm{H}_{14} \mathrm{Fe}_{2} \mathrm{O}_{8} \mathrm{~S}_{2}$ : C, 40.48; H, 2.64; S, 12.00. Found, C, 40.31; H, 2.74; S, 12.20 .

Complex $4 p$ (20\%). ${ }^{1} \mathrm{H}$ NMR $\left(300 \mathrm{MHz}, \mathrm{CDCl}_{3}\right) \delta 2.10(\mathrm{dd}, 2 \mathrm{H}, J$ $\left.=13.1,5.6 \mathrm{~Hz}, \mathrm{CH}_{2} \mathrm{~S}\right), 2.75\left(\mathrm{dd}, 2 \mathrm{H}, J=13.1,7.5 \mathrm{~Hz}, \mathrm{CH}_{2} \mathrm{~S}\right), 2.97-$ 3.06 (m, 2H, CHS), 3.79 (dd, $2 \mathrm{H}, J=9.7,7.0 \mathrm{~Hz}, \mathrm{OCH}_{2}$ ), 3.96 (dd, $\left.2 \mathrm{H}, J=9.7,5.6 \mathrm{~Hz}, \mathrm{OCH}_{2}\right), 6.81(\mathrm{~s}, 4 \mathrm{H}, \mathrm{Ar}) .{ }^{13} \mathrm{C} \mathrm{NMR}(75 \mathrm{MHz}$, $\left.\mathrm{CDCl}_{3}\right) \delta 208.3,152.9,115.8,70.7,52.6,39.1$. IR (film): $\nu 2075$, 2032, 1985, 1506, $1223 \mathrm{~cm}^{-1}$. Anal. calcd for $\mathrm{C}_{24} \mathrm{H}_{14} \mathrm{Fe}_{4} \mathrm{O}_{14} \mathrm{~S}_{4}: \mathrm{C}$, 32.83; H, 1.61; S, 14.61. Found, C, 33.11; H, 1.97; S, 15.10.

\section{Crystal data for compound $4 d$}

$\mathrm{C}_{16} \mathrm{H}_{7} \mathrm{Fe}_{2} \mathrm{NO}_{8} \mathrm{~S}_{2}, M=517.05$, monoclinic, $a=13.23734(18), b=$ 7.41493(10), $c=18.8284(2) \AA$, $\beta=92.6332(12)^{\circ}, V=1846.13 \AA^{3}$, space group $P_{2(1) / \mathrm{c}}, Z=4, T=120(2) \mathrm{K}, \lambda=0.71073 \AA$, $D_{\text {calcd }}=$ $1.860 \mathrm{~g} \mathrm{~cm}^{-3}, \mu=1.844 \mathrm{~cm}^{-1}, 42161$ reflections measured, 6112 unique $\left(R_{\text {int }}=0.0427\right)$, dark red tablets obtained by $\mathrm{CH}_{2} \mathrm{Cl}_{2} / n$-hexane diffusion, crystal structure solved by dualspace methods with all non-hydrogen atoms refined anisotropically on $F^{2}$ using the programs SHELXT ${ }^{30}$ and SHELXL$2018,{ }^{31}$ hydrogen atoms were included using a riding model, $\mathrm{GOF}=1.028, R(\mathrm{Fo}, I>2 \sigma(I))=0.0270, R_{\mathrm{w}}\left(\mathrm{Fo}^{2}\right.$, all data $)=$ 0.0610 .

\section{Conflicts of interest}

The authors declare no competing financial interest.

\section{Acknowledgements}

Support for this work under grants CTQ2016-77555-C2-1-R and CTQ2016-81797-REDC (Programa Redes Consolider) from the AEI (Spain) is gratefully acknowledged. MAS thanks the Fundación Ramón Areces for a grant from the XVIII Concurso Nacional de Ayudas a la Investigación en Ciencias de la Vida y de la Materia (CIVP18A3938).

\section{References}

1 (a) Hydrogen as a Fuel: Learning from Nature, ed. R. Cammack, M. Frey and R. Robson, Taylor\&Francis, 2001; (b) Compendium of Hydrogen Energy Volume 1: Hydrogen Production and Purification, ed. V. Subramani, A. Basile and T. N. Veziroğlu, Elsevier, 2015; (c) I. Dincer and C. Zamfirescu, Sustainable Hydrogen Production, Elsevier, 2016; (d) Compendium of Hydrogen Energy Volume 4: Hydrogen Use, Safety and the Hydrogen Economy, ed. M. Ball, A. Basile and T. N. Veziroğlu, Elsevier, 2016; (e) J. Corredor, M. J. Rivero, C. M. Rangel, F. Gloaguen and I. Ortiz, J. Chem. Technol. Biotechnol., 2019, 94, 3049-3063.

2 (a) W. Lubitz, H. Ogata, O. Rüdiger and W. Reijerse, Chem. Rev., 2014, 114, 4081-4148; (b) P. M. Vignais and B. Billoud, Chem. Rev., 2007, 107, 4206-4272.

3 See, for example: (a) E. Reisner, D. J. Powell, C. Cavazza, J. C. Fontecilla-Camps and F. A. Armstrong, J. Am. Chem. 
Soc., 2009, 131, 18457-18466; (b) K. A. S. Brown, S. Dayal, X. Ai, G. Rumbles and P. W. King, J. Am. Chem. Soc., 2010, 132, 9672-9680; (c) K. A. Brown, B. Wilker, M. Boehm, G. Dukovic and P. W. King, J. Am. Chem. Soc., 2012, 134, 5627-5636; (d) Y. Honda, H. Hagiwara, S. Ida and T. Ishihara, Angew. Chem. Int. Ed., 2016, 55, 8045-8048; Angew. Chem., 2016, 128, 8177-8180.

4 Revisions: (a) L. Schilter, J. M. Camara, M. T. Huynh, S. Hammes-Schiffer and T. B. Rauchfuss, Chem. Rev., 2016, 116, 8693-8749; (b) Y. Li and T. B. Rauchfuss, Chem. Rev., 2016, 116, 7043-7077; (c) F. Gloaguen, Inorg. Chem., 2016, 55, 390-398Representative examples: (d) H. Li and T. B. Rauchfuss, J. Am. Chem. Soc., 2002, 124, 726-727; (e) Y. Na, J. Pan, M. Wang and L. Sun, Inorg. Chem., 2007, 46, 3813-3815; ( $f$ ) S. Gao, J. Fan, S. Sun, X. Peng, X. Zhao and J. Hou, Dalton Trans., 2008, 2128-2135; $(g)$ P. Li, M. Wang, L. Chen, J. Liu, Z. Zhao and L. Sun, Dalton Trans., 2009, 1919-1926; (h) U.-P. Apfel, D. Troegel, Y. Halpin, S. Tschierlei, U. Uhlemann, H. Görls, M. Schmitt, J. Popp, P. Dunne, M. Venkatesan, M. Coey, M. Rudolph, J. G. Vos, R. Tacke and W. Weigand, Inorg. Chem., 2010, 49, 1011710132; (i) J. M. Camara and T. B. Rauchfuss, Nat. Chem., 2012, 4, 26-30; (j) D. Zheng, M. Wang, L. Chen, N. Wang and L. Sun, Inorg. Chem., 2014, 53, 1555-1561; $(k)$ T. Yu, Y. Zeng, J. Chen, Y.-Y. Li, G. Yang and Y. Li, Angew. Chem. Int. Ed., 2013, 52, 5631-5635; Angew. Chem., 2013, 125, 5741-5745.

5 An alternative route to incorporate moieties II and III in substrates incompatible with the standard synthetic approaches to these compounds is the use of $\mathrm{Fe}_{2}[(\mu-$ $\left.\left.\mathrm{SCH}_{2}\right)_{2}\left(\mathrm{NC}_{6} \mathrm{H}_{4} \mathrm{~N}_{3}\right)\right](\mathrm{CO})_{6}$ reagents through a $\mathrm{Cu}$-catalyzed alkyne-azide cycloaddition. See, A. D. Merinero, A. Collado, L. Casarrubios, M. Gómez-Gallego, C. Ramírez de Arellano, A. Caballero, F. Zapata and M. A. Sierra, Inorg. Chem., 2019, 58, 16267-16278.

6 A. Kramer and I.-P. Lorenz, J. Organomet. Chem., 1990, 388, 187-193.

7 A. Kramer, R. Lingnau, I.-P. Lorenz and H. A. Mayer, Chem. Ber., 1990, 123, 1821-1826.

8 J. Messelhäuser, K. U. Gutensohn, I.-P. Lorenz and W. Hiller, J. Organomet. Chem., 1987, 371, 377-388.

9 R. D. Adams and S. Miao, Inorg. Chem., 2004, 43, 8414-8426.

10 M. D. Westmeyer, T. B. Rauchfuss and A. K. Verma, Inorg. Chem., 1996, 35, 7140-7147.

11 Selected examples from these laboratorios $(a)$ I. Fernández, F. P. Cossío and M. A. Sierra, Acc. Chem. Res., 2011, 44, 479-490; (b) I. Fernández and M. A. Sierra, Top. Heterocycl. Chem., 2013, 30, 65-84; (c) A. Santiago, M. A. GómezGallego, C. Ramírez de Arellano and M. A. Sierra, Chem. Commun., 2013, 49, 1112-1115; (d) G. M. Chu, I. Fernández and M. A. Sierra, Chem.-Eur. J., 2013, 19, 5899-908; (e) J. G. Muntaner, L. Casarrubios and M. A. Sierra, Org. Biomol. Chem., 2014, 11, 286-297; (f) A. R. Rivero, I. Fernández and M. A. Sierra, Chem.-Eur. J., 2014, 20, 1359-1366; $(g)$ G. M. Chu, A. Guerrero-Martínez, I. Fernández and M. A. Sierra, Chem.-Eur. J., 2014, 20, 1367-1375; (h) B. Eguillor, M. A. Esteruelas, I. Fernández,
M. Gómez-Gallego, M. Martín-Ortiz, M. Oliván and M. A. Sierra, Organometallics, 2015, 34, 1898-1910; (i) G. M. Chu, I. Fernández, A. Guerrero-Martínez, C. Ramírez de Arellano and M. A. Sierra, Eur. J. Inorg. Chem., 2016, 844-852; (j) G. M. Chu, I. Fernández, A. Guerrero-Martínez, C. Ramírez de Arellano and M. A. Sierra, Inorg. Chem., 2016, 55, 2737-2747.

12 L. E. Bogan, D. A. Lesch and T. B. Rauchfuss, J. Organomet. Chem., 1983, 250, 429-438.

13 Good yields for the synthesis of alkyne adducts similar to 4 have been reported by the reaction of the lithium salts of terminal alkynes with $\left[(\mu-S)_{2} \mathrm{Fe}_{2}(\mathrm{CO})\right]$ and subsequent addition of acid in: (a) D. Seyferth, G. G. Womack and L. C. Song, Organometallics, 1983, 2, 776-779; (b) D. Seyferth and G. B. Womack, Organometallics, 1986, 5, 2360-2370.

1491 structures found in CSD-5.4 October 2019; C. R. Groom, I. J. Bruno, M. P. Lightfoot and S. C. Ward, The Cambridge Structural Database, Acta Crystallogr., 2016, B72, 171-191.

15 (a) Y. Nicolet, A. L. Lacey, X. Vernéde, V. M. Fernandez, E. C. Hatchikian and J. C. Fontecilla-Camps, J. Am. Chem. Soc., 2001, 123, 1596-1601; (b) J. W. Peters, W. N. Lanzilotta, B. J. Lemon and L. C. Seefeldt, Science, 1998, 282, 1853-1858.

16 D. Braga, F. Grepioni, K. Biradha, V. R. Pedireddi and G. R. Desiraju, J. Am. Chem. Soc., 1995, 117, 3156-3166.

17 (a) T. Liu, M. Wang, Z. Shi, H. Cui, W. Dong, J. Chen, B. Åkermark and L. Sun, Chem.-Eur. J., 2004, 10, 44744479; (b) S. Gao, J. Fan, S. Sun, X. Peng, X. Zhao and J. Hou, Dalton Trans., 2008, 10, 2128-2135.

18 I. Silaghi-Dumitrescu, T. E. Bitterwolf and R. B. King, J. Am. Chem. Soc., 2006, 128, 5342-5343.

19 We can hypothesize that decomposition of these products may be responsible for the lower yields experimentally observed when using alkynes instead of olefins as starting materials. However, decomposition was never observed under our reaction conditions and unreacted alkyne was recovered in all cases.

20 The triplet state stepwise mechanism in Scheme 8 occurs through a zwitterionic intermediate that may rotate leading to partial or complete loss of the stereochemistry of the starting olefin. The torquoselectivity of reactions involving these species has been profusely studied. For examples from these laboratories, see: F. P. Cossío, A. Arrieta and M. A. Sierra, Acc. Chem. Res., 2008, 41, 925936.

21 G. A. N. Felton, A. K. Vannucci, J. Chen, L. T. Lockett, N. Okumura, B. J. Petro, U. I. Zakai, D. H. Evans, R. S. Glass and D. L. Lichtenberger, J. Am. Chem. Soc., 2007, 129, 12521-12530.

22 The electrochemistry of complex $\mathbf{4 h}$ was reported previously: K. Charreteur, M. Kdider, J.-F. Capon, F. Gloaguen, F. Y. Pétillon, P. Schollhammer and J. Talarmin, Inorg. Chem., 2010, 49, 2496-2501. These authors reported that this complex was unstable in MeCN/NnBu4PF6 and electrochemical data were not given in this solvent. In our hands complex $\mathbf{4 h}$ was stable and electrochemistry could 
be measured without incidences. The reduction potentials measured in dichloromethane parallels our findings in MeCN (see text).

23 For a similar behavior, see: (a) M. G. Avello, M. C. de la Torre, M. A. Sierra, H. Gornitzka and C. Hemmert, Chem.-Eur. J., 2019, 25, 13344-13353; (b) S.-H. Wu, J.-J. Shen, J. Yao and Y.-W. Zhong, Chem.-Asian J., 2013, 8, 138-147, and the pertinent references therein.

24 G. A. N. Felton, R. S. Glass, D. L. Lichtenberger and D. H. Evans, Inorg. Chem., 2006, 45, 9181-9184.

25 G. A. N. Felton, A. K. Vannucci, J. Chen, L. T. Lockett, N. Okumura, B. J. Petro, U. I. Zakai, D. H. Evans, R. S. Glass and D. L. Lichtenberger, J. Am. Chem. Soc., 2007, 129, 12521-12530.

26 (a) J. F. Capon, F. Gloaguen, P. Schollhammer and J. Talarmin, J. Electroanal. Chem., 2004, 566, 241-247; (b) J. F. Capon, F. Gloaguen, P. Schollhammer and J. Talarmin, J. Electroanal. Chem., 2006, 595, 47-52.

27 M. J. Frisch, G. W. Trucks, H. B. Schlegel, G. E. Scuseria, M. A. Robb, J. R. Cheeseman, G. Scalmani, V. Barone, B. Mennucci, G. A. Petersson, H. Nakatsuji, M. Caricato, X. Li, H. P. Hratchian, A. F. Izmaylov, J. Bloino, G. Zheng, J. L. Sonnenberg, M. Hada, M. Ehara, K. Toyota, R. Fukuda, J. Hasegawa, M. Ishida, T. Nakajima, Y. Honda, O. Kitao, H. Nakai, T. Vreven, J. A. Montgomery, Jr,
J. E. Peralta, F. Ogliaro, M. Bearpark, J. J. Heyd, E. Brothers, K. N. Kudin, V. N. Staroverov, T. Keith, R. Kobayashi, J. Normand, K. Raghavachari, A. Rendell, J. C. Burant, S. S. Iyengar, J. Tomasi, M. Cossi, N. Rega, J. M. Millam, M. Klene, J. E. Knox, J. B. Cross, V. Bakken, C. Adamo, J. Jaramillo, R. Gomperts, R. E. Stratmann, O. Yazyev, A. J. Austin, R. Cammi, C. Pomelli, J. W. Ochterski, R. L. Martin, K. Morokuma, V. G. Zakrzewski, G. A. Voth, P. Salvador, J. J. Dannenberg, S. Dapprich, A. D. Daniels, O. Farkas, J. B. Foresman, J. V. Ortiz, J. Cioslowski and D. J. Fox, Gaussian 09, Revision, D.01, Gaussian, Inc., Wallingford CT, 2013.

28 (a) A. D. Becke, Phys. Rev. A Gen. Phys., 1988, 38, 3098-3100; (b) F. Weigend and R. Ahlrichs, Phys. Chem. Chem. Phys., 2005, 7, 3297-3305; (c) F. Weigend, Phys. Chem. Chem. Phys., 2008, 8, 1057-1065.

29 (a) V. Barone and M. Cossi, J. Phys. Chem. A, 1988, 102, 19952001; (b) M. Cossi, N. Rega, G. Scalmani and V. Barone, J. Comput. Chem., 2003, 24, 669-681.

30 G. M. Sheldrick, SHELXT- Integrated space-group and crystal-structure determination, Acta Crystallogr., Sect. A: Found. Adv., 2015, 71, 3.

31 G. M. Sheldrick, Acta Crystallogr., Sect. C: Struct. Chem., 2015, $71,3-8$. 